\title{
Transfection of Sertoli cells with androgen receptor alters gene expression without androgen stimulation
}

\author{
D. Fietz ${ }^{1 *+}$, M. Markmann² ${ }^{2 \dagger}$ D. Lang ${ }^{1 \dagger}$, L. Konrad ${ }^{3}$, J. Geyer $^{1}$, S. Kliesch ${ }^{4}$, T. Chakraborty ${ }^{2}$, H. Hossain ${ }^{2}$ \\ and M. Bergmann ${ }^{1}$
}

\begin{abstract}
Background: Androgens play an important role for the development of male fertility and gained interest as growth and survival factors for certain types of cancer. Androgens act via the androgen receptor (AR/Ar), which is involved in various cell biological processes such as sex differentiation. To study the functional mechanisms of androgen action, cell culture systems and AR-transfected cell lines are needed. Transfection of AR into cell lines and subsequent gene expression analysis after androgen treatment is well established to investigate the molecular biology of target cells. However, it remains unclear how the transfection with AR itself can modulate the gene expression even without androgen stimulation. Therefore, we transfected Ar-deficient rat Sertoli cells 93 RS2 by electroporation using a full length human AR.
\end{abstract}

Results: Transfection success was confirmed by Western Blotting, immunofluorescence and RT-PCR. AR transfectionrelated gene expression alterations were detected with microarray-based genome-wide expression profiling of transfected and non-transfected 93RS2 cells without androgen stimulation. Microarray analysis revealed 672 differentially regulated genes with 200 up- and 472 down-regulated genes. These genes could be assigned to four major biological categories (development, hormone response, immune response and metabolism). Microarray results were confirmed by quantitative RT-PCR analysis for 22 candidate genes.

Conclusion: We conclude from our data, that the transfection of Ar-deficient Sertoli cells with AR has a measurable effect on gene expression even without androgen stimulation and cause Sertoli cell damage. Studies using ARtransfected cells, subsequently stimulated, should consider alterations in AR-dependent gene expression as off-target effects of the AR transfection itself.

Keywords: Transfection, Gene expression analysis, Androgen receptor, Sertoli cells

\section{Background}

Androgens play a pivotal role for the development of the male phenotype, the initiation and maintenance of spermatogenesis and therefore male fertility (for review see [1]). The action of the most important androgens testosterone $(\mathrm{T})$ and dihydrotestosterone (DHT) is mediated by the androgen receptor $(\mathrm{AR} / A r)$. It is a ligand-activated

\footnotetext{
*Correspondence: Daniela.Fietz@vetmed.uni-giessen.de

${ }^{\dagger}$ D. Fietz, M. Markmann, D. Lang contributed equally to the study

${ }^{1}$ Institute of Veterinary Anatomy, Histology and Embryology, Justus

Liebig University, Frankfurter Straße 98, 35392 Giessen, Germany

Full list of author information is available at the end of the article
}

transcriptional factor belonging to the nuclear receptor superfamily. The AR/Ar gene is located on the $\mathrm{X}$ chromosome and consists of eight exons, coding for the $\mathrm{N}$-terminal transcription regulation domain, the DNA binding domain (DBD) in the middle of the protein and the C-terminal ligand binding domain (LBD). The DBD as well as the LBD are highly conserved throughout species (for review see [2]). Bound to its ligand, the androgen-AR complex is translocated into the nucleus, binds to the DNA (androgen responsive elements, AREs) and is able to activate or repress gene expression by recruiting co-activators or co-repressors (for review see [3]). The 
activity of steroid hormone receptors is also regulated by post-transcriptional modifications. In case of $\mathrm{AR} / A r$, a great variety of these modifications has been described, i.e. phosphorylation, acetylation, ubiquitination and also methylation (for review see [4]).

The AR/Ar is expressed in all tissues except the spleen (for review see [2]). In the testis, it is expressed in interstitial Leydig cells and endothelial cells, as well as in peritubular myoid cells and tubular Sertoli cells [5], for review see [1]. Since germ cells do not express $\mathrm{AR} / A r$, the androgen action has to be mediated towards the germ cells by Sertoli cells. These somatic cells have been described as branched cells surrounding all germ cell stages $[6,7]$. As was shown by Willems et al. [8], a selective ablation of $A r$ in mouse Sertoli cells (SCARKO) leads to a disturbed Sertoli cell maturation including a delayed and defective establishment of the blood-testis barrier. Moreover, no meiotic germ cells were observed in SCARKO mice, showing the importance of a functional AR/Ar on Sertoli cell biology and for the development of germ cells.

To examine the role of the $\mathrm{AR} / \mathrm{Ar}$ in different biological processes such as cell growth and survival as well as AR/Ar-dependent gene expression, cell culture systems are needed. Therefore, administration of $\mathrm{T}$ and/or the more efficient metabolite DHT has widely been used to investigate the effect of androgens and $\mathrm{AR} / \mathrm{Ar}$, respectively, in diverse cultured cells such as human breast cancer cells, adrenocortical carcinoma cells, murine skeletal muscle cells or liver carcinoma cells [9-12]. Additionally, AR/Ar-deficient cell lines were used, e.g. AR-deficient MCF-7 breast cancer cells, to examine the effect on estrogen administration in a system lacking AR [13]. Szelei et al. [14] transfected AR-deficient MCF-7 breast cancer cells with human AR and showed an inhibition of proliferation. Also prostate cancer cells devoid of AR were transfected with human AR and showed a decreased proliferation rate [15]. The question is, whether the transfection procedure itself might have led to an altered expression of $\mathrm{AR} / A r$-dependent and $\mathrm{AR} / A r$-independent genes. Xiao et al. [16] demonstrated equal concerns in Amh-Cre-transfected mouse, where an increase of oxidative stress and lipid peroxidation in Sertoli cells was detected even without stimulation.

Beside "classical" androgen-dependent prostate cancer development, also androgen-independent signalling pathways gained increasing interest as shown recently by Li et al. [17]. The authors describe a persistent transcriptional activity in castration-resistant prostate cancer cell lines in the absence of androgens. This transcriptional activity was mediated by a truncated AR protein lacking the LBD. This raises the question, whether an androgenindependent $\mathrm{AR} / \mathrm{Ar}$ action is always important in cell biology and which genes might be expressed or repressed by AR/Ar presence alone.

For this purpose, we transfected rat Sertoli cells which have been shown to be deficient of $A r$ with full length human AR DNA. After transfection, we performed genome-wide microarray analysis and compared the gene expression pattern with non-transfected Sertoli cells to identify a possible "intrinsic" activity of AR/Ar without androgen administration. We found significantly altered gene expression in transfected compared with non-transfected cells, possibly influencing Sertoli cell function.

\section{Results}

\section{Transfection of 93RS2 cells with the human AR}

Performing RT-PCR with primers specific for mouse and rat $A r$, respectively, rat Sertoli cells (93RS2, [18]) proved to lack endogenous $A r$ (Fig. 1) and were therefore chosen for further experiments.

Success of transfection with full length human AR CDS was validated by immunofluorescence (IF, Fig. 2a), Western Blot (Fig. 2b) and RT-PCR (Fig. 2c). As the commercially available human AR was introduced in a GFP-coupled vector system, we used a rabbit anti-GFP antibody for IF experiments in transfected cells whereas non-transfected cells were used as internal negative control. Using PAGE, we were able to show the CAG repeat length of 17 to be stable throughout different settings (Fig. 2d).

\section{Microarray analysis revealed an altered gene expression in transfected 93RS2 cells}

Microarray analysis revealed 672 significantly regulated genes $(\mathrm{p}<0.01$ and fold change $(\mathrm{FC}) \geq 2.0$ ). Of these, 200

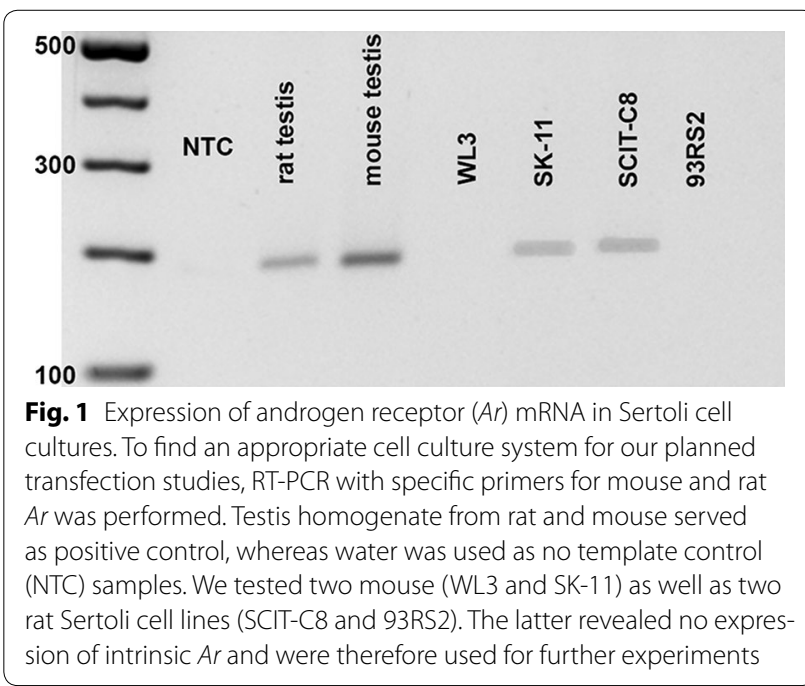



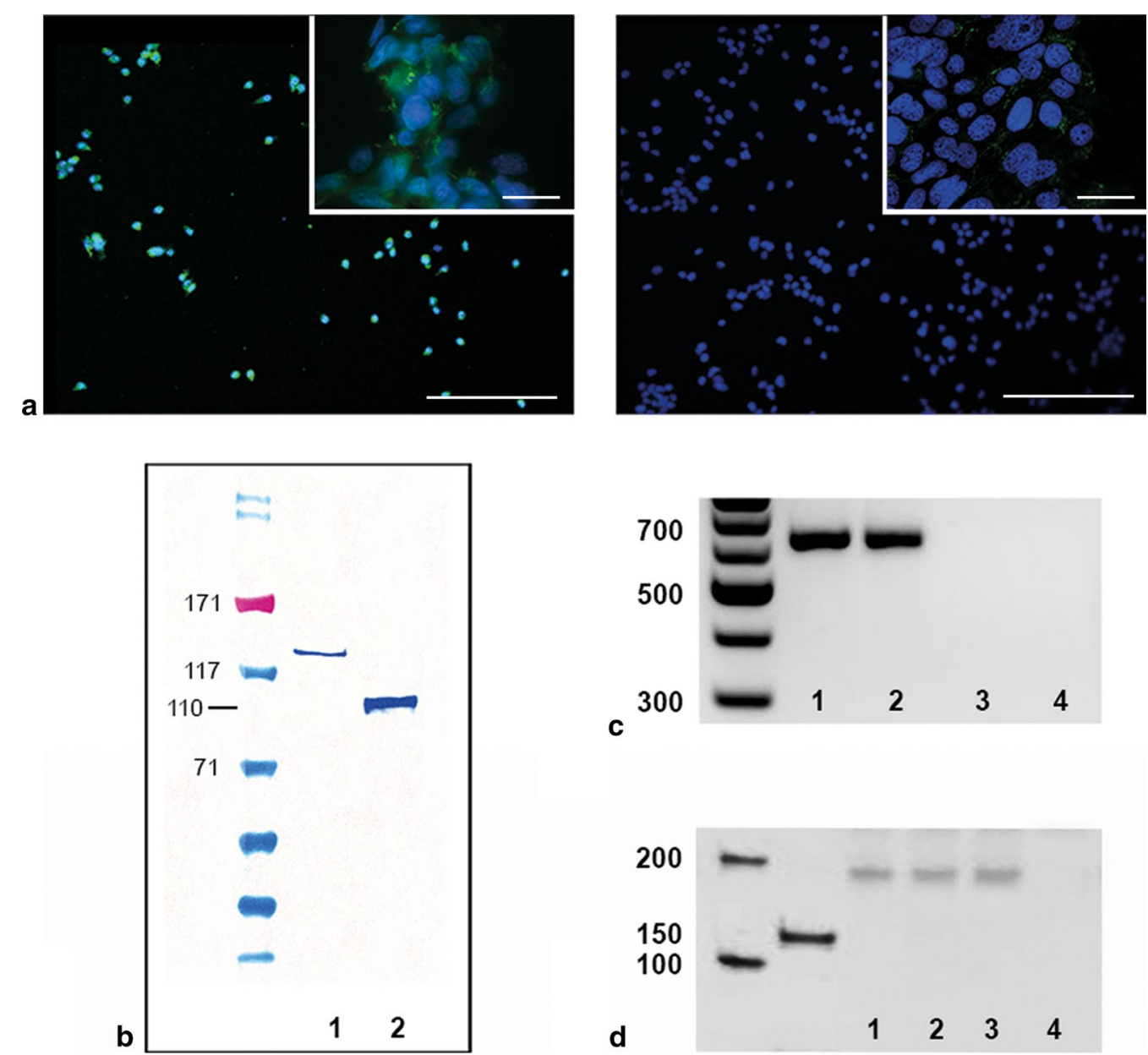

Fig. 2 Transfection control of 93RS2 Sertoli cells. a $24 \mathrm{~h}$ after transfection, transfected (a) and non-transfected (b) cells as negative control were fixed for IF experiments. left Incubation with rabbit anti-GFP antibody showed successful transfection of almost $80 \%$ of cells. right No staining signal was detectable in non-transfected cells. Scale bars in main image: $200 \mu \mathrm{m}$, detail: $25 \mu \mathrm{m}$. DAPI counterstain. b Western Blot analysis revealed AR protein in transfected Sertoli cells at approx. $135 \mathrm{kDa}$ (1) and in human testis tissue at the expected molecular weight of $110 \mathrm{kDa}$ (2). The higher protein weight measured in transfected cells is due to coupling of AR with GFP. $\mathbf{c}$ Expression of human AR mRNA was tested in human testis homogenate (1), transfected (2) and non-transfected cells (3). AR mRNA was detected in the positive control and transfected 93RS2hAR17 cells, but not in non-transfected cells and the NTC (lane 4). d To control the CAG repeat length in transfected 93RS2 cells, we performed high-resolution PAGE. Three different passages of 93RShAR17 cells (lanes 1-3) were analysed and revealed a band for human AR at 185 bp by using two different DNA ladders. By sequencing, 185 bp was shown to be typical for the presence of 17 CAG repeats. Lane 4 no template control (NTC)

genes showed higher gene expression values, whereas 472 revealed a lower gene expression in 93RShAR17 cells compared with non-transfected cells.

Hierarchical clustering of the 672 significantly regulated genes shows two clusters clearly differentiating between transfected and non-transfected cells (Fig. 3). Three biological replicates have been tested and show a homogeneous expression pattern, indicating high reproducibility of microarray results. An overview of the ten highest regulated genes for down- and up-regulation is given in Table 1. Complete array data may be found following the link provided [19].
“Development", “Hormone response” and “Immune response" are the predominant functions of the differently regulated genes

Of 370 annotated down-regulated genes, 330 could be assigned to DAVID functional categories, and 124 out of 142 annotated up-regulated genes, respectively.

An overview of the functional categories that have been inferred with DAVID is given in Table 2. Down-regulation is predominant in "Cell development/Cell contact", "Response to hormone stimulus" and "Nucleotide catabolic process", whereas regulation is evenly distributed in "Immune response". The highest score values are achieved by four 


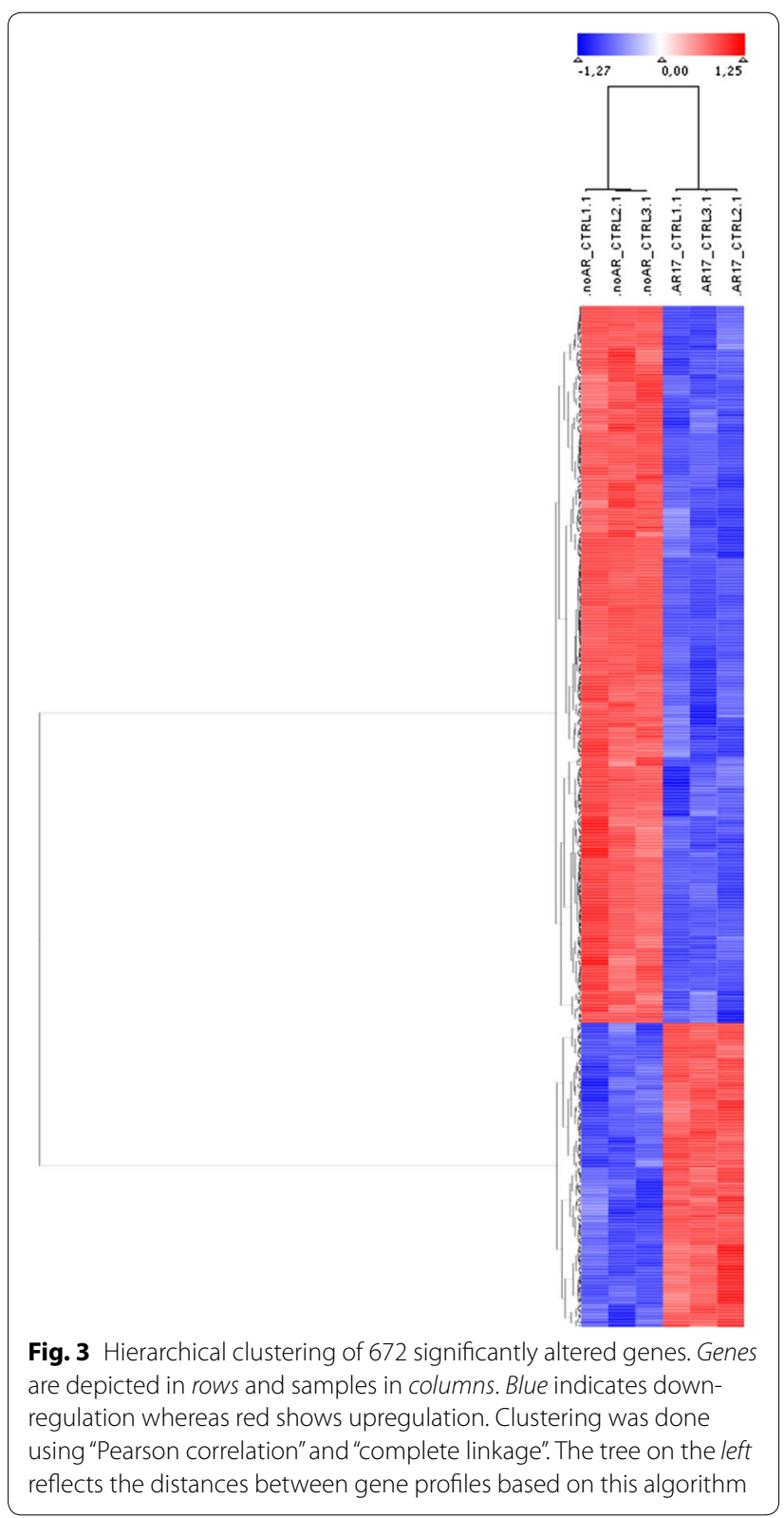

significantly overrepresented gene ontology (GO) categories clustered under "Biological adhesion", whereas the highest number of genes is assigned to $15 \mathrm{GO}$ categories grouped as a cluster named "Epithelium development". More than half of the functional assigned groups belong to cell development and cell contact while $25 \%$ of the functionally assigned genes are related to immune response. 36 genes can be attributed to "Hormone stimulus" and a minority of 12 genes contributes to "Nucleotide catabolic process".

\section{Upstream regulation analysis identified more activation than de-activation}

Upstream regulation analysis with IPA is based on gene expression patterns and predicts activation or deactivation of regulators of the differentially regulated genes. The results show that more upstream regulators are predicted to be activated $(\mathrm{n}=51)$ than inhibited $(n=20)$.

These predictions are based on 220 genes from which 95 contributed to activation as well as to deactivation. The proportion of overall down- and up-regulation is mirrored in these genes with more down-regulation in inhibition as well as in activation (Tables 3, 4, 5, 6). The majority of deactivated upstream regulators ( 8 out of 20 ) are classified as transcription regulators. Activation is mainly predicted for cytokines (14 out of 51).

\section{Validation of microarray data by RT-qPCR}

For validation of microarray results we performed RTqPCR for 22 candidate genes, showing different ranges of regulation (up, down). Among the chosen genes, some are mainly associated with development and are known Sertoli cell markers, such as Dhh [20], Gja1 [21], Inhbb [22], and $T f$ [23]. Other genes are markers for differentiation and proliferation (e.g. Bambi and Tgfb1i1 [24]) and some are involved in apoptosis, such as Myc and Tnfrsfla [25]. Results from RT-qPCR were mostly consistent with data from microarray analysis (Fig. 4). Relative gene expression was lower in transfected compared to nontransfected Sertoli cells in 13 of 22 cases. Gene expression of Cdkn1a, Egr1, Fst, Gja1, Myc, Pmepa1, Ptsg2, Rarg and Tnfrsfla was higher in 93RShAR17 cells compared to Ar-deficient 93RS2 cells. In the latter case, it has to be mentioned, that differences of the means did not reach significance in four genes, due to high variability of $\mathrm{C}_{\mathrm{q}}$.

\section{Discussion}

To study the effects of androgens and AR/Ar on diverse cell culture systems and the relevance for cell biology, cell culture experiments were conducted in different human cell lines (e.g. breast cancer cells, adrenocortical carcinoma cells, murine skeletal muscle cells or liver carcinoma cells [9-12]). Also AR-deficient cell lines have been used, either transfected with $\operatorname{AR}[14,15]$ or without [13]. Both groups working with transfected cell lines performed their experiments using either not stimulated [14] or mock-transfected cells [15] as negative controls. Moreover, Jacobsen et al. [26] showed, that transfection of MCF-7 breast cancer cells lead to severe differences in gene expression levels in distinct genes, depending on the transfection reagent used. Interestingly, transfection with a vector encoding for a reporter gene and a vector without insert, respectively, revealed no differences in gene expression. This implies, that the transfection procedure itself might alter gene expression in these cells. Therefore, we performed gene expression analysis with AR-transfected rat Sertoli cells using non-transfected 


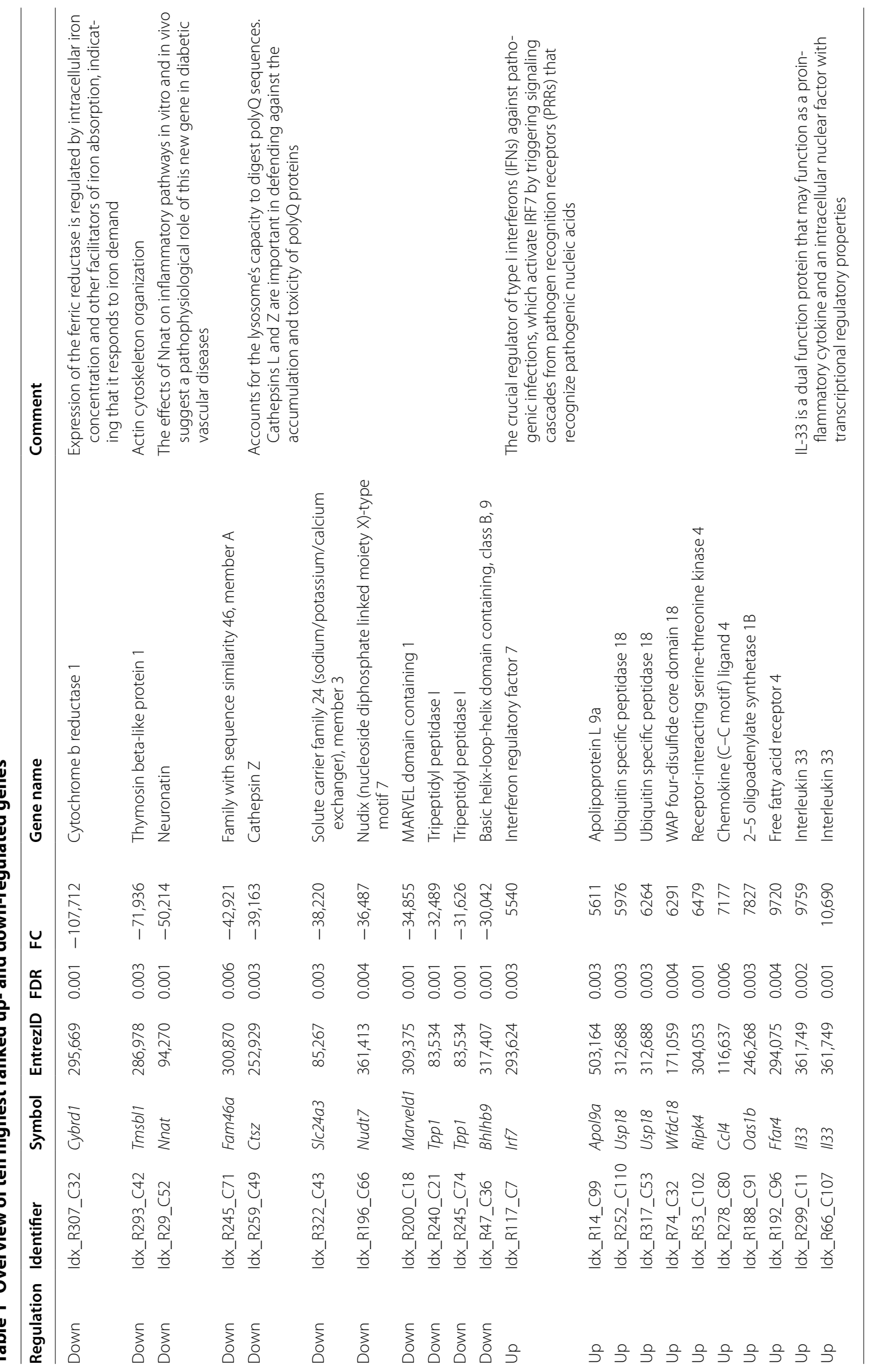




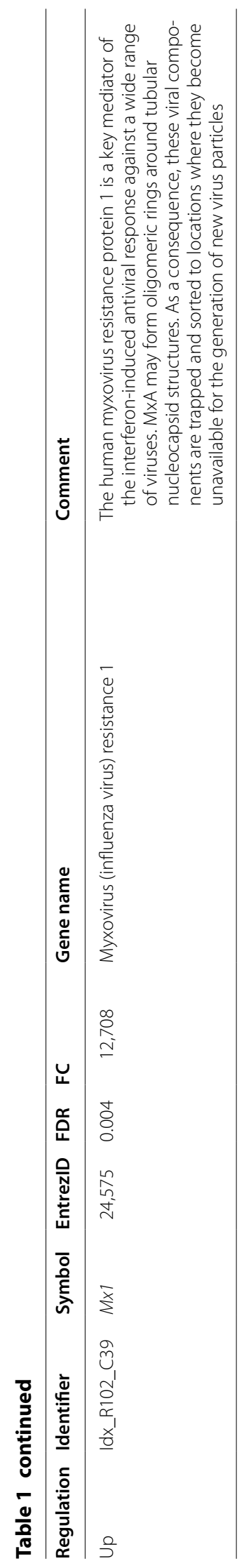


Table 2 Overview of functional gene ontology categories according to their pattern of significantly regulated genes

\begin{tabular}{|c|c|c|c|c|c|}
\hline Group & Cluster\# & Cluster of GO categories & Score & & Symbols \\
\hline \multirow[t]{8}{*}{ Cell development/cell contact [106] } & 1 & Biological adhesion (4) [25] & 2.27 & Up & $\begin{array}{l}\text { Vnn1, Amigo2, Bcam, Cdh2, Ceacam1, } \\
\text { Col12a1, Col14a1, Col16a1, Dsg2, Gpc1, } \\
\text { Mcam, Omd, Sned1, Col18a1, Ctgf, Gpr56, } \\
\text { Ncam1, Igfbp7 }\end{array}$ \\
\hline & & & & Down & Itgb8, F5, Pcdh1, Pcdh18, Plcxd2, Ptprm, Ctgf \\
\hline & 3 & Axonogenesis (13) [36] & 1.89 & Up & $\begin{array}{l}\text { Aldh1a2, Apbb1, Apoe, Boc, Cd24, Cdkn1c, } \\
\text { Chn2, Col18a1, Col18a1, Cxcl12, Efna2, } \\
\text { Efnb1, Fgfr2, Gli2, Gpc2, H19, Hoxc10, } \\
\text { Krt19, Lpar3, Nnat, Nrep, Obs11, Pmp22, } \\
\text { Ppp1r9a, Prickle2, Sdc2, Sema4f, Shroom3, } \\
\text { Sox5, Uchl1 }\end{array}$ \\
\hline & & & & Down & Ptprm, Epha7, Dpys/3, Mtss 1, Nes, Sgk1 \\
\hline & 4 & Retinoid metabolic process (5) [8] & 1.75 & Up & Akr7a3, Aldh1a2, As3mt, Ldhb, Rarres2, Rbp 1 \\
\hline & & & & Down & Crabp2, Rbp2 \\
\hline & 7 & Epithelium development (15) [50] & 1.47 & Up & $\begin{array}{l}\text { Acp5, Adamts1, Adck3, Aldh1a2, Celsr1, } \\
\text { Col18a1, Col1a1, Col4a1, Cxcl12, Disp1, } \\
\text { Efna2, Efnb1, Fbn1, Fgfr2, Foxe1, Fox12, Gli2, } \\
\text { H19, Hmx2, Hoxc10, Irf6, Kazn, Mgp, Mn1, } \\
\text { Mycn, Pgf, Plce1, Serpinf1, Sfrp2, Shroom3, } \\
\text { Sox5, Spry1, Srgn, Tbx18, Tbx4, Tek, Tgfb1i1, } \\
\text { Tgm2, Upk1b }\end{array}$ \\
\hline & & & & Down & $\begin{array}{l}\text { Ctgf, Crabp2, Fst, Ptger2, Rsad2, Cdx2, Hoxb6, } \\
\text { Krt14, Ptgs2, Foxp2, Myc }\end{array}$ \\
\hline \multirow[t]{2}{*}{$H[36]$} & 2 & $\begin{array}{l}\text { Response to steroid hormone stimulus } \\
\text { (10) [36] }\end{array}$ & 1.90 & Up & $\begin{array}{l}\text { Acp5, Adamts1, Adck3, Aldh1a2, Apoe, Boc, } \\
\text { Cd24, Celsr1, Colla1, Cxcl12, Disp1, Efna2, } \\
\text { Efnb1, Fgfr2, Gli2, Gpr56, H19, Igfbp7, Krt19, } \\
\text { Lpar3, Mgp, Ncam1, Nnat, Pgf, Plcel, Sdc2, } \\
\text { Serpinf1, Sfrp2, Tek, Tgfb111, Tgm2 }\end{array}$ \\
\hline & & & & Down & Foxp2, Myc, Nes, Ptgs2, Sgk1 \\
\hline \multirow[t]{4}{*}{ Immune response [55] } & 5 & Innate immune response (4) [34] & 1.69 & Up & $\begin{array}{l}\text { Acp5, Adck3, Afap 112, Apbb1, C2, Cd24, } \\
\text { Cxcl12, Cyp4f6, II27ra, Masp1, Ptpn6, RT1- } \\
\text { DMb, Tf, Tgm2, Tinagl1, Tlr2, Vnn1, Zfr2 }\end{array}$ \\
\hline & & & & Down & $\begin{array}{l}\text { A2 m, C3ar1, Ccl2, Ccl4, Ereg, F2rl1, Gch1, } \\
\text { Il1rl1, Irf7, Irgm, Nppb, Oas1b, Oasl2, Prg4, } \\
\text { Ptgs2, Rsad2 }\end{array}$ \\
\hline & 8 & $\begin{array}{l}\text { Cell surface receptor linked signal trans- } \\
\text { duction (3) [25] }\end{array}$ & 1.35 & Up & $\begin{array}{l}\text { Adamts1, Adck3, Apoe, Boc, Cd24, Celsr1, } \\
\text { Cxcl12, Disp1, Efna2, Efnb1, Fgfr2, Gli2, } \\
\text { Gpr56, Lpar3, Ncam1, Plce1, Sfrp2, Tek, } \\
\text { Tgfb1i1, Tgm2 }\end{array}$ \\
\hline & & & & Down & Ctgf, Epha7, Fst, Itgb8, Ptger2 \\
\hline \multirow[t]{2}{*}{$N[12]$} & 6 & Nucleotide catabolic process (7) [12] & 1.47 & Up & $\begin{array}{l}\text { Akr7a3, Ampd3, Gucy 1b3, Nt5e, Nudt7, } \\
\text { Pde4a, Pde4b, Prodh }\end{array}$ \\
\hline & & & & Down & Gch1, Nppb, Ppat, Upp1 \\
\hline
\end{tabular}

Numbers in normal brackets denote the number of grouped GO categories. Absolute numbers of regulated genes per main group are given in squared brackets, examples of regulated genes are shown for up- and down-regulated genes

$H$ hormone stimulus, $N$ Nucleotide Catabolic Process

cells as controls to show "intrinsic" gene expression alterations due to the transfection procedure. As electroporation has been shown to be superior with respect to cell viability and also transfection efficiency compared to chemical transfection using lipofectamine [27], we applied this technique to introduce the AR. Cell viability was not influenced by electroporation, but whole genome microarray analysis showed an altered gene expression. Surprisingly, more genes have been down-regulated than up-regulated comparing transfected and non-transfected cells. We selected 22 genes showing an altered expression pattern and confirmed microarray results with RT-qPCR analysis. In the following, we will discuss in more depth interesting genes and pathways, respectively.

Among the down-regulated genes, many are involved in metabolic processes, as for example in iron transport and metabolism (cytochrome $\mathrm{b}$ reductase 1 (Cybrd1), $\mathrm{FC}=-107$; transferrin $(T f), \mathrm{FC}=-6,898$; 
Table 3 Upstream regulator analysis with IPA: types of predicted upstream regulators

\begin{tabular}{llll}
\hline Activation $(\mathbf{n = 5 1 )}$ & & Inhibition $(\mathbf{n}=\mathbf{2 0})$ & \\
\hline Cytokines/group of cytokines & 14 & Transcription regulator & 8 \\
Others/complex of others & 8 & Cytokine & 2 \\
Kinases, group of kinases & 8 & Enzyme & 2 \\
$\begin{array}{l}\text { Growth factors/complex of } \\
\quad 6\end{array}$ & 6 & Other & 2 \\
$\quad$ growth factors & & & \\
Transcription regulator & 6 & G-protein coupled receptor & 1 \\
$\begin{array}{l}\text { Transmembrene receptors } \\
\text { Enzymes }\end{array}$ & 4 & Growth factor & 1 \\
& 3 & Ligand-dependent nuclear & 1 \\
Ligand-dependent nuclear & 1 & Peptidase & 1 \\
$\quad$ receptor & & & 1 \\
Peptidase & 1 & Phosphatase & 1 \\
& & Transporter &
\end{tabular}

Summarizing the regulator according to their type revealed a high proportion of possibly activated cytokines, whereas transcription regulators play a major role in inhibition

Based on gene expression patterns, predictions are made on activation or inactivation of known upstream regulators. Absolute activation z-scores of higher than 2.0 are considered to be highly significant. We found more than twice as much regulators predicted to be activated as compared to inhibited. These tables show the predicted upstream regulators with an absolute $z$-score above 2.0 in detail-some are in fact complexes or groups. The prediction is opposed to the real measurement on the micro array (rightmost columns), as far as the respective genes have passed QC and is otherwise marked as "not measured". Mean expression per group is given as logarithm of the intensity to base 2 . Reasonably high expression values are in bold face. The column "regulation AR17" denotes if the respective gene is contained in the set of regulated genes (level $=\mathrm{L} 1$ ) or at least close to significance (level $=\mathrm{L} 2$ / L3) which holds true for the minority of genes. Activation or inhibition is not necessarily reflected by significant change of gene expression, since processes not measurable on a micro array, like for example phosphorylation, are more likely to be responsible for that

Table 4 Upstream regulator analysis with IPA: proportion of up- and downregulated genes

\begin{tabular}{llcc}
\hline Gene pattern & Activation only & Inhibition only & Both \\
\hline Down regulation & 64 & 28 & 50 \\
Up regulation & 28 & 5 & 45
\end{tabular}

The gene expression patterns upon which the prediction is made is constituted by both up-regulated and down-regulated genes. The predicted activation and inhibition is either based on two third down regulated $(n=114 / n=78)$ and one third upregulated genes $(n=73 / n=50) .50$ downregulated genes and 45 upregulated genes contribute likewise to activation and inhibition (The details of the contributing gens are not shown here)

Based on gene expression patterns, predictions are made on activation or inactivation of known upstream regulators. Absolute activation z-scores of higher than 2.0 are considered to be highly significant. We found more than twice as much regulators predicted to be activated as compared to inhibited. These tables show the predicted upstream regulators with an absolute $z$-score above 2.0 in detail-some are in fact complexes or groups. The prediction is opposed to the real measurement on the micro array (rightmost columns), as far as the respective genes have passed QC and is otherwise marked as "not measured". Mean expression per group is given as logarithm of the intensity to base 2 . Reasonably high expression values are in bold face. The column "regulation AR17" denotes if the respective gene is contained in the set of regulated genes (level $=\mathrm{L} 1$ ) or at least close to significance (level $=\mathrm{L} 2 / \mathrm{L} 3$ ) which holds true for the minority of genes. Activation or inhibition is not necessarily reflected by significant change of gene expression, since processes not measurable on a micro array, like for example phosphorylation, are more likely to be responsible for that six-transmembrane epithelial antigen of the prostate 2 (Steap2), FC $=-2.3$ ). Iron is relevant for Sertoli cells in two different aspects: as supervisors of germ cell development, Sertoli cells provide iron which is needed for DNA synthesis and cell growth of germ cells that undergo multiple mitotic divisions [28]. On the other hand, Sertoli cells avoid toxic environmental conditions that might be given at elevated concentrations of insoluble ferric iron $\left(\mathrm{Fe}^{3+}\right)$. Therefore, Sertoli cells secrete transferrin, the product of the $T f$ gene [29], which may be used as a marker for Sertoli cell function and differentiation [23] as it creates an environment low in free iron that impedes bacterial survival in a process called iron withholding. The protein level of $T f$ decreases in inflammation. The lower expression of $T f$ gene, which was confirmed in RTqPCR (Fig. 4), could be interpreted as a sign of severe disturbance and inflammation of cells.

The latter is reflected by the high proportion of upstream regulators related to immune response (= cytokines and members of the MAP kinase signalling pathway) that are predicted to be activated (Table 3) and the presence of multiple immune response-related genes on top of the list in up-regulation (Table 1). "Immune response" is the second huge cluster of altered genes in our study, represented by e.g. prostaglandin-endoperoxidase synthase 2 (Ptgs2, FC $=3.558)$ also known as cyclooxygenase 2 (Cox2). An increase in Cox2 expression was observed by Matzkin et al. [30] in Leydig cells of infertile men showing either hypospermatogenesis, Sertoli cell only syndrome or maturational arrest. By increased numbers of testicular macrophages, levels of interleukin $1 \beta(I l-1 \beta)$ are increased and activates Ptgs 2 , the key enzyme in prostaglandin synthesis culminating in inflammation. The expression of Tf, Ptgs 2 and interleukins is coupled in Sertoli cells; as shown by Yamaguchi et al. [31], incubation with cisplatin lead to an increase in Ptgs 2 and a decrease in $T f$ expression in Sertoli cell cultures, similar to our study. Additionally, an analysis of upstream regulation using IPA revealed a high number of key players in inflammation to be activated showing congruently high FCs for $\mathrm{Ccl} 5$, Irf7, and Ifnb1. This might on the one side be due to the transfection procedure itself and/or reflect inflammatory processes in the cells due to increased cell damage. Remarkably, an influence of molecular biological techniques on gene expression and immune response has been observed also in regard to short-interfering RNAs (siRNAs). Sledz et al. reported an induction of interferon $\beta$ levels in a human glioblastoma cell line which was transfected with siRNAs as a non-specific side effect additionally to the silencing of the target gene lamin [32] . 
Table 5 Upstream regulator analysis with IPA: predicted activated regulators

\begin{tabular}{|c|c|c|c|c|c|c|c|}
\hline \multicolumn{3}{|l|}{ IPA-prediction } & \multicolumn{5}{|c|}{ Micro array analysis } \\
\hline Upstream regulator & Molecule type & z-score & FDR & FC & Mean AR17 & Mean noAR & Regulation AR17 [level] \\
\hline Ahr & Ligand-dependent nuclear receptor & 3.185 & 0.895 & -1.017 & -1.219 & -1.194 & \\
\hline Bmp6 & Growth factor & 2.791 & 0.011 & -1.483 & 2.595 & 3.164 & \\
\hline $\mathrm{CCl} 5$ & Cytokine & 2.190 & 0.016 & 2.529 & 2.922 & 1.583 & {$[U p$ L3] } \\
\hline$D d \times 58$ & Enzyme & 2.789 & 0.019 & 2.096 & 3.316 & 2.249 & {$[U p$ L3] } \\
\hline Dock8 & Other & 2.530 & 0.010 & -1.656 & 2.545 & 3.272 & [Down L2] \\
\hline Egf & Growth factor & 2.539 & & \multicolumn{2}{|c|}{$<$ not measured $>$} & & \\
\hline Erk: & Group of kinases $(n=7)$ & 2.372 & & & $<$ group $>$ & & \\
\hline Mapk1 & Kinase & & 0.009 & -1.019 & 3.670 & 3.697 & \\
\hline Mapk3 & Kinase & & 0.027 & -1.280 & 5.646 & 6.002 & \\
\hline Mapk4 & Kinase & & 0.701 & 1.086 & -2.321 & -2.440 & \\
\hline Mapk6 & Kinase & & 0.037 & 1.131 & 5.152 & 4.975 & \\
\hline Mapk7 & Kinase & & 0.758 & -1.047 & 2.862 & 2.928 & \\
\hline Mapk12 & Kinase & & 0.018 & -2.005 & 0.121 & 1.125 & [Down L3] \\
\hline Mapk15 & Kinase & & 0.208 & 1.217 & 0.507 & 0.224 & \\
\hline Mek: & Group of kinases $(n=7)$ & 2.942 & & & <group> & & \\
\hline Map2k1 & Kinase & & 0.105 & 1.182 & 4.651 & 4.410 & \\
\hline Map2k2 & Kinase & & 0.177 & 1.090 & 4.816 & 4.691 & \\
\hline Map2k3 & Kinase & & -1.066 & -0.092 & 4.360 & 4.452 & \\
\hline Map2k4 & Kinase & & 1.023 & 0.032 & 3.336 & 3.303 & \\
\hline Map2k5 & Kinase & & -1.058 & -0.082 & 3.327 & 3.408 & \\
\hline Map2k6 & Kinase & & 1.177 & 0.235 & 3.760 & 3.525 & \\
\hline Map2k7 & Kinase & & -1.125 & -0.170 & -1.445 & -1.275 & \\
\hline P38 Mapk: & Group of kinases $(n=5)$ & 2.624 & & & <group > & & \\
\hline Mapk1 & Kinase & & 0.009 & -1.019 & 3.670 & 3.697 & \\
\hline Mapk11 & Kinase & & 0.087 & -1.343 & 0.139 & 0.565 & \\
\hline Mapk12 & Kinase & & & $<$ see $a b c$ & & & \\
\hline Mapk13 & Kinase & & & $<$ notme & ured $>$ & & \\
\hline Mapk14 & Kinase & & 0.046 & -1.276 & 3.242 & 3.594 & \\
\hline Mapk2/1: group of & Kinases $(n=2)$ & 2.401 & & & $<$ group $>$ & & \\
\hline Map2k1 & Kinase & & & $<$ see $a b c$ & & & \\
\hline Map2k2 & Kinase & & & $<$ see $a b c$ & & & \\
\hline$F 7$ & Peptidase & 2.592 & & $<$ notme & ured $>$ & & \\
\hline Fgf2 & Growth factor & 2.085 & 0.122 & 1.178 & 0.417 & 0.180 & \\
\hline Fos & Transcription regulator & 2.086 & 0.069 & -1.425 & 2.972 & 3.482 & \\
\hline Hras & Enzyme & 3.258 & & $<$ notme & ured> & & \\
\hline Ifn /Ifn alpha: & Group of groups & & & & & & \\
\hline Ifn: & Group of cytokines & 2.429 & & & $<$ group $>$ & & \\
\hline Ifn alpha: & Group of cytokines & 2.228 & & & $<$ group > & & \\
\hline Ifnal & Cytokine & & 0.104 & 1.306 & 2.728 & 2.343 & \\
\hline Ifna2 & Cytokine & 2.448 & & $<$ notme & ured $>$ & & \\
\hline Ifna4 & Cytokine & 2.236 & & $<$ notme & ured $>$ & & \\
\hline Ifna5-8 & cyTokine $(n=4)$ & & & $<$ notme & ured $>$ & & \\
\hline Ifna $10,13,14,16,17,21$ & Cytokine $(n=6)$ & & & $<$ notme & ured $>$ & & \\
\hline Ifnk & Cytokine & & & $<$ notme & ured $>$ & & \\
\hline Ifnw1 & Cytokine & & & $<$ notme & ured $>$ & & \\
\hline Ifnz & Cytokine & & & $<$ notme & ured> & & \\
\hline Ifn beta: & Group of cytokines $(n=2)$ & 2.767 & & & & & \\
\hline$|f n b|$ & Cytokine & 2.591 & 0.079 & 2.953 & -1.949 & -3.511 & \\
\hline 116 & Cytokine & 2.443 & 0.014 & 1.481 & -0.730 & -1.296 & \\
\hline Ifnar: & Group of transmembrane receptors & 2.749 & & & $<$ group $>$ & & \\
\hline Ifnar1 & Transmembrane receptor & & & $<$ notme & ured> & & \\
\hline
\end{tabular}


Table 5 continued

\begin{tabular}{|c|c|c|c|c|c|c|c|}
\hline \multicolumn{3}{|l|}{ IPA-prediction } & \multicolumn{5}{|c|}{ Micro array analysis } \\
\hline Upstream regulator & Molecule type & z-score & FDR & FC & Mean AR17 & Mean noAR & Regulation AR17 [level] \\
\hline Ifnar2 & Transmembrane receptor & & & \multicolumn{4}{|c|}{$<$ not measured $>$} \\
\hline Ifne & Cytokine & 2.219 & & \multicolumn{2}{|c|}{$<$ not measured $>$} & & \\
\hline Ifng & Cytokine & 2.811 & & \multicolumn{2}{|c|}{$<$ not measured $>$} & & \\
\hline$|f n| 1$ & Cytokine & 2.764 & & \multicolumn{2}{|c|}{$<$ not measured $>$} & & \\
\hline $\lg 2$ & Growth factor & 2.213 & 0.001 & -9.285 & 1.909 & 5.124 & [Down L1] \\
\hline Ikbke & Kinase & 2.090 & 0.013 & -2.034 & -1.262 & -0.238 & [Down L3] \\
\hline 111: group of & Cytokines $(n=11)$ & 2.207 & & & & & \\
\hline 1116 & Cytokine & & & \multicolumn{2}{|c|}{$<$ not measured $>$} & & \\
\hline 1118 & Cytokine & 2.372 & 0.300 & -1.056 & 0.531 & 0.610 & \\
\hline $111 f 10$ & Cytokine & & 0.689 & 1.102 & -2.284 & -2.424 & \\
\hline$\| 1 r n$ & Cytokine & & 0.009 & 1.812 & 0.062 & -0.796 & [Up L2] \\
\hline 1133 & Cytokine & & 0.001 & 10.690 & 1.998 & -1.420 & {$[U p$ L1] } \\
\hline $1117 a$ & Cytokine & & & \multicolumn{2}{|c|}{$<$ not measured $>$} & & \\
\hline $1136 a$ & Cytokine & & & \multicolumn{2}{|c|}{$<$ not measured $>$} & & \\
\hline $1136 b$ & Cytokine & & & \multicolumn{2}{|c|}{$<$ not measured $>$} & & \\
\hline $1136 g$ & Cytokine & & & \multicolumn{2}{|c|}{$<$ not measured $>$} & & \\
\hline $1136 r n$ & Cytokine & & 0.019 & 1.393 & 2.076 & 1.598 & \\
\hline 1137 & Cytokine & & & \multicolumn{2}{|c|}{$<$ not measured $>$} & & \\
\hline Irf3 & Transcription regulator & 3.157 & 0.520 & 1.336 & 3.450 & 3.033 & \\
\hline Irf5 & Transcription regulator & 2.934 & 0.113 & 1.096 & 1.321 & 1.188 & \\
\hline Irf7 & Transcription regulator & 3.901 & 0.003 & 5.540 & 5.574 & 3.104 & {$[U p$ L1] } \\
\hline Kras & Enzyme & 2.616 & 0.191 & -1.097 & 3.119 & 3.253 & \\
\hline $\operatorname{Lh}[\mathrm{Cg} a, \operatorname{Lhb}]$ & Complex & 2.012 & & & & & \\
\hline Lhb & Other & & 0.480 & 1.044 & 2.593 & 2.530 & \\
\hline Cga & Other & & 0.251 & 1.273 & -0.193 & -0.541 & \\
\hline Map3k7 & Kinase & 2.375 & 0.352 & -1.067 & 4.577 & 4.671 & \\
\hline Mavs & Other & 2.630 & 0.021 & -1.231 & 2.569 & 2.868 & \\
\hline Pdgfbb & Complex & 3.491 & & & $<$ group $>$ & & \\
\hline$P d g f b$ & Growth factor & & & 1.156 & 2.037 & 1.828 & \\
\hline Pdlim2 & Other & 2.324 & 0.003 & 1.346 & 3.226 & 2.798 & \\
\hline Samsn1 & Other & 2.309 & & \multicolumn{2}{|c|}{$<$ not measured $>$} & & \\
\hline Sash1 & Other & 2.530 & & \multicolumn{2}{|c|}{$<$ not measured $>$} & & \\
\hline Sphk1 & Kinase & 2.172 & 0.611 & 1.237 & -0.033 & -0.341 & \\
\hline Src & Kinase & 2.158 & 0.033 & 1.348 & 3.704 & 3.273 & \\
\hline Stat1 & Transcription regulator & 2.194 & 0.013 & 1.375 & 3.163 & 2.703 & \\
\hline Stat2 & Transcription regulator & 2.173 & 0.535 & 1.067 & 3.865 & 3.772 & \\
\hline Tac1 & Other & 2.153 & 0.910 & 1.055 & -2.385 & -2.462 & \\
\hline Tgfa & Growth factor & 2.165 & 0.586 & 1.088 & 2.152 & 2.031 & \\
\hline Ticam 1 & Other & 2.702 & 0.574 & -1.035 & 3.646 & 3.696 & \\
\hline $\operatorname{Tlr3}$ & Transmembrane receptor & 3.633 & 0.049 & -1.414 & -0.244 & 0.256 & \\
\hline Tlr 4 & Transmembrane receptor & 3.175 & & \multicolumn{2}{|c|}{$<$ not measured $>$} & & \\
\hline $\operatorname{Tlr} 9$ & Transmembrane receptor & 3.645 & 0.249 & 1.134 & 2.534 & 2.353 & \\
\hline Tnfsfil & Cytokine & 2.168 & 0.539 & 1.115 & -0.643 & -0.800 & \\
\hline
\end{tabular}

Z-score $<2.0$

Based on gene expression patterns, predictions are made on activation or inactivation of known upstream regulators. Absolute activation z-scores of higher than 2.0 are considered to be highly significant. We found more than twice as much regulators predicted to be activated as compared to inhibited. These tables show the predicted upstream regulators with an absolute $z$-score above 2.0 in detail-some are in fact complexes or groups. The prediction is opposed to the real measurement on the micro array (rightmost columns), as far as the respective genes have passed QC and is otherwise marked as "not measured". Mean expression per group is given as logarithm of the intensity to base 2 . Reasonably high expression values are in bold face. The column "regulation AR17" denotes if the respective gene is contained in the set of regulated genes (level $=\mathrm{L} 1$ ) or at least close to significance (level $=\mathrm{L} 2 / \mathrm{L} 3$ ) which holds true for the minority of genes. Activation or inhibition is not necessarily reflected by significant change of gene expression, since processes not measurable on a micro array, like for example phosphorylation, are more likely to be responsible for that 
Table 6 Upstream regulator analysis with IPA: Predicted inactivated regulators

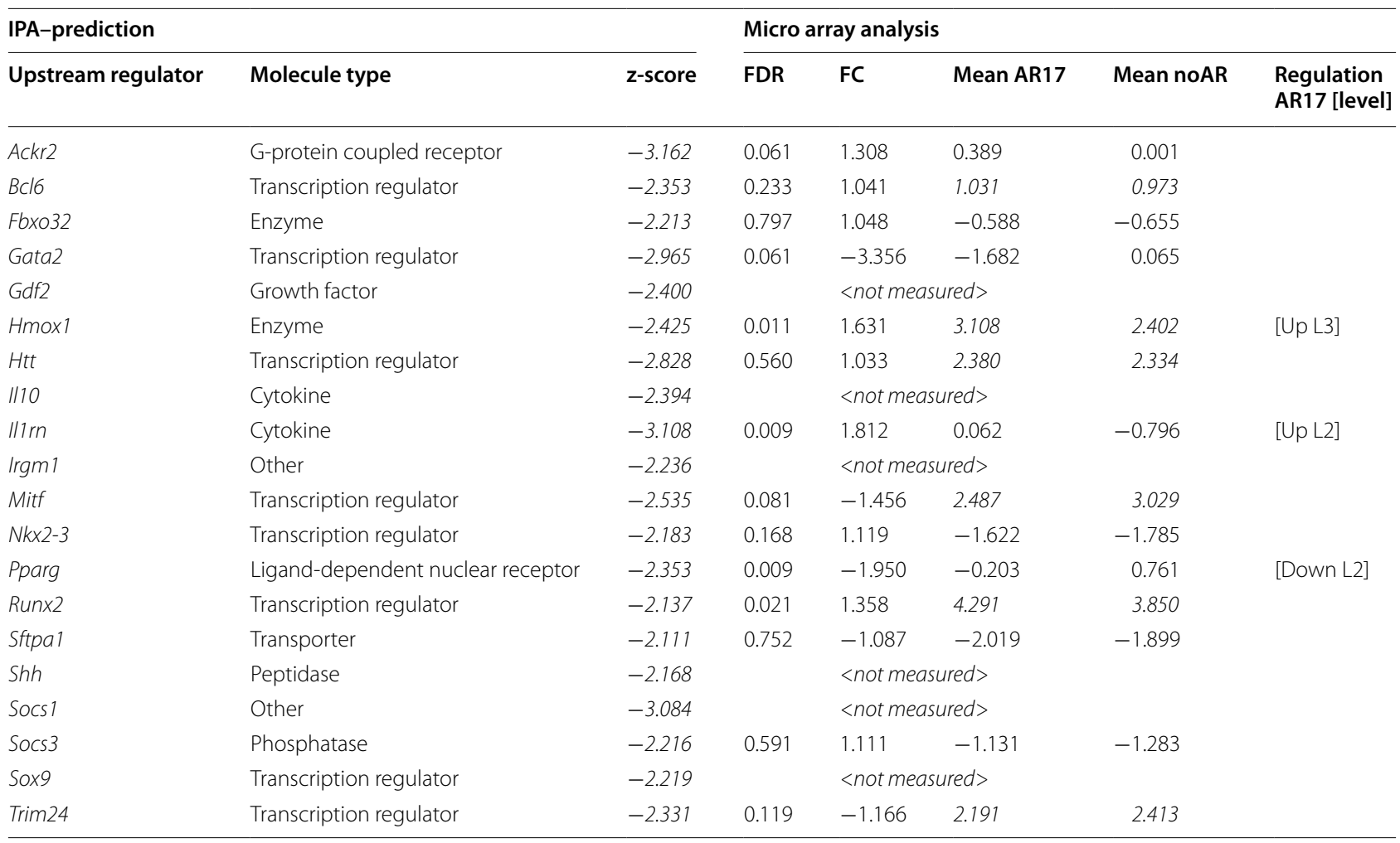

Z-score $<-2.0$

Based on gene expression patterns, predictions are made on activation or inactivation of known upstream regulators. Absolute activation z-scores of higher than 2.0 are considered to be highly significant. We found more than twice as much regulators predicted to be activated as compared to inhibited. These tables show the predicted upstream regulators with an absolute $z$-score above 2.0 in detail-some are in fact complexes or groups. The prediction is opposed to the real measurement on the micro array (rightmost columns), as far as the respective genes have passed QC and is otherwise marked as "not measured". Mean expression per group is given as logarithm of the intensity to base 2 . Reasonably high expression values are in bold face. The column "regulation AR17" denotes if the respective gene is contained in the set of regulated genes (level $=\mathrm{L} 1$ ) or at least close to significance (level $=\mathrm{L} 2 / \mathrm{L} 3$ ) which holds true for the minority of genes. Activation or inhibition is not necessarily reflected by significant change of gene expression, since processes not measurable on a micro array, like for example phosphorylation, are more likely to be responsible for that

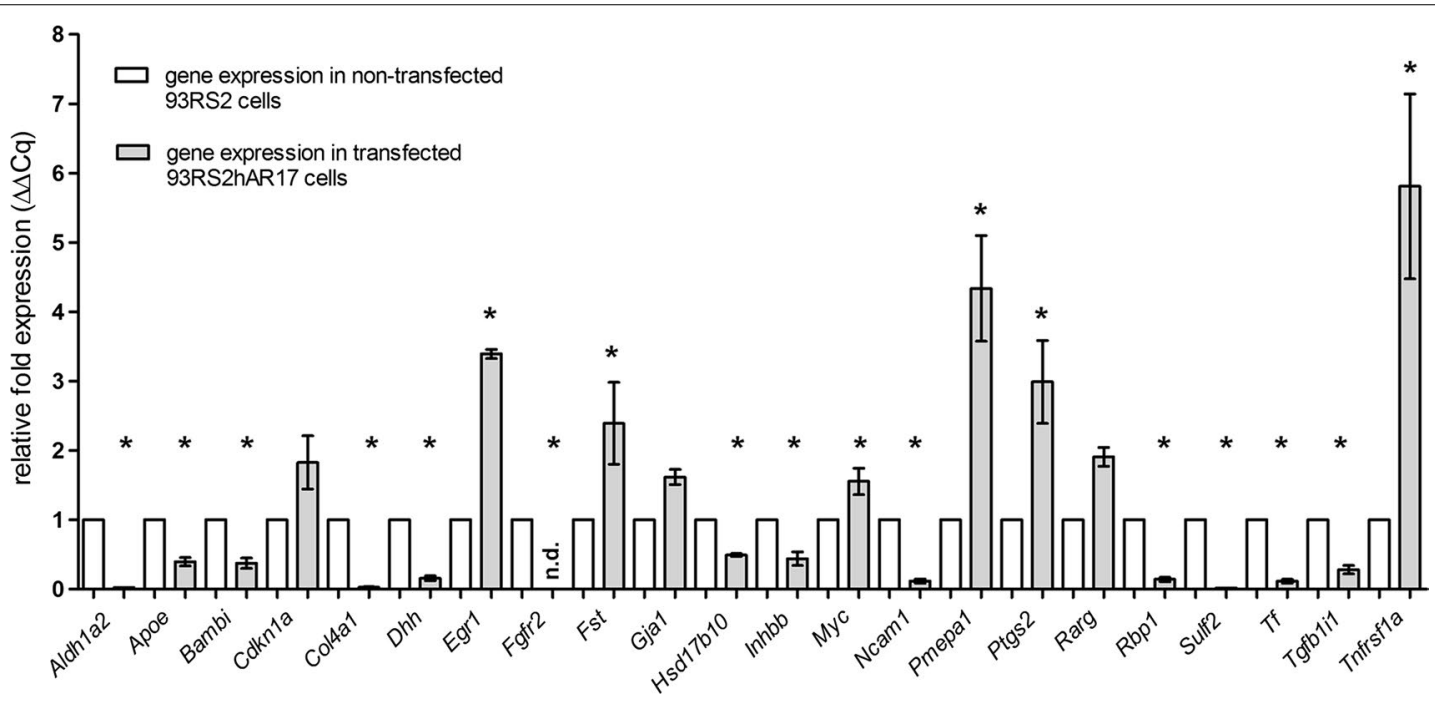

Fig. 4 Quantitative RT-PCR was performed to validate microarray analysis results. Gene expression analysis for 22 genes that showed deviant gene expression in microarray analysis has been performed using $2^{-\Delta \Delta C a}$ method. RT-qPCR has been performed using three technical replicates in a double determination. Gene expression in non-transfected 93RS2 cells was used as calibrator and therefore set as "1". Data are presented as mean \pm SEM. (standard error of the mean) and differences in mean values have been assessed with SPSS software; ${ }^{*} p \leq 0.05, n$.d. not detectable 


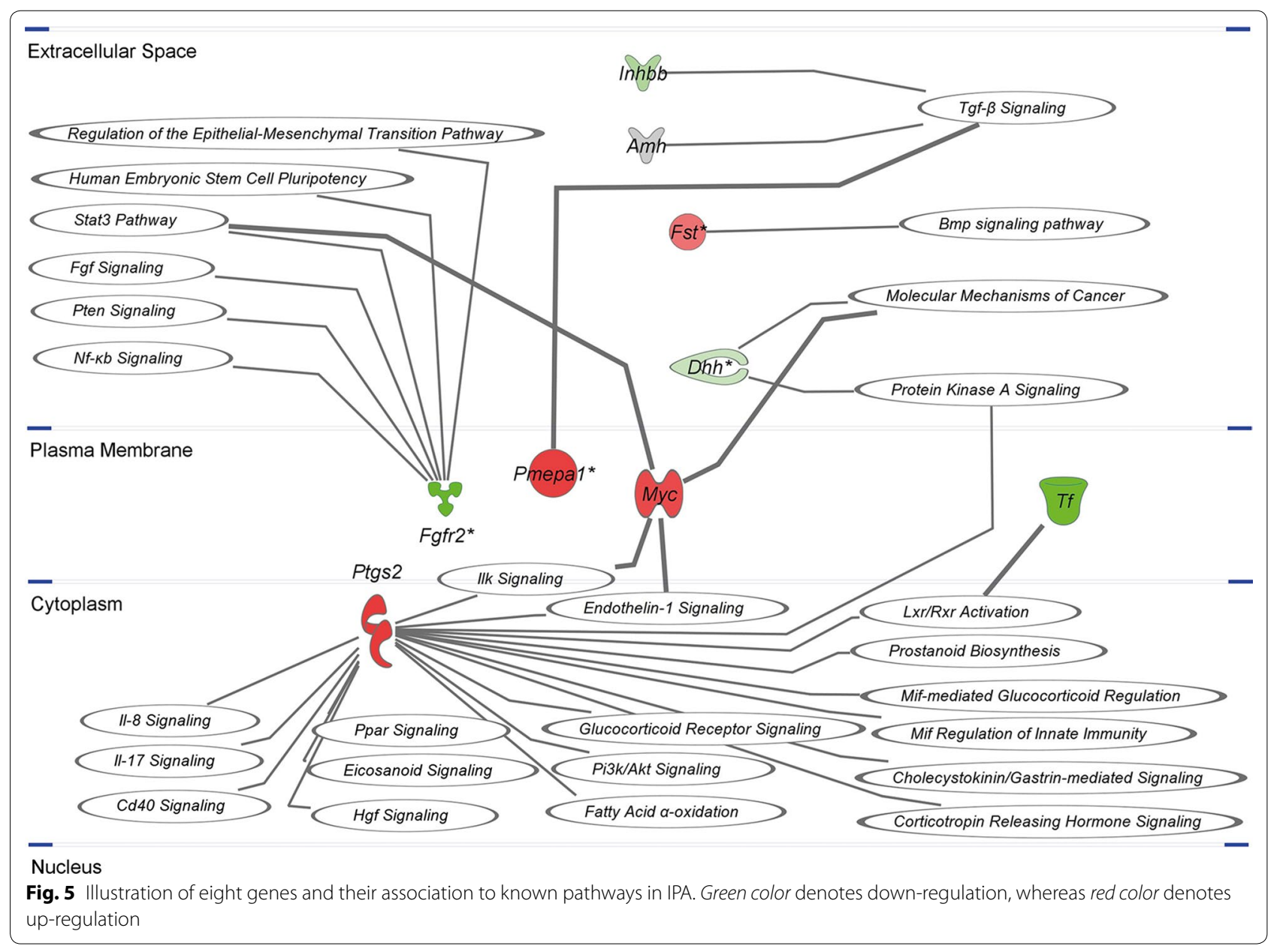

Not only metabolism and immune response gene expression seem to be altered in transfected Sertoli cells, but also cell cycle and development genes (desert hedge hog $(D h h) \mathrm{FC}=-2.032$; fibroblast growth factor receptor 2 (Fgfr2) $\mathrm{FC}=-8.239$; follistatin (Fst) $\mathrm{FC}=2.162$; inhibin beta $\mathrm{b}($ Inhbb) FC $=-3.126)$. Dhh is involved in various areas of embryonic development, including testicular cord formation. It is expressed in mouse Sertoli cell precursors during mid- to late gestation [33] and also is important for germ cell development after puberty in mouse [34] and rat testis [35]. In the mouse, a lack of Dhh results in a severe impairment of spermatogenesis due to a lack of spermatogonial development beyond primary spermatocytes [34]. Fgfr2 is a known differentiation factor in prenatal Sertoli cells as it is concomitantly expressed with $S r y$ and is essential for subsequent expression of anti-muellerian hormone $(A m h)$ and Sox9 [36]. IPA analysis of upstream regulation predicted an inhibition of transcription factor Sox 9 with a z-score of -2.2 (Table 6). Moreover, lack of Fgfr 2 might cause a partial $\mathrm{XY}$ sex reversal, as loss of Fgfr2 leads to an up-regulation of Follistatin (Fst), a female somatic cell marker [37], which was confirmed by microarray and RT-qPCR. A down-regulation of the Sertoli cell marker Inhbb (for review see [38]) also points to a decreased Sertoli cell function and a severe disturbance of spermatogenesis in the rat [39]. Figure 5 shows the association of Inhbb, Fst, Dhh, Pmepa1, Fgfr2, Ptgs2, Tf and Myc as especially interesting genes on known pathways as predicted by IPA.

A disturbance of Sertoli cell function is also visible in gene expression alteration concerning the functional cluster "Cell adherence" or "Cell adhesion" (Fig. 6, e.g. collagen type IV alpha (Col4a1) $\mathrm{FC}=-12.503$; gap junction protein 1 (Gja1) FC $=-1.188$ ). Cell adhesion and formation of tight junctions between Sertoli cells generating the blood-testis barrier is one of the most important features of Sertoli cell maturation and function (for review see [22]) as it is a prerequisite for intact spermatogenesis. Also cell-to-cell contact and communication seem to be disturbed in transfected cells as indicated by the down-regulation of Gja1, also known as connexin 43 (for review see [20]). 


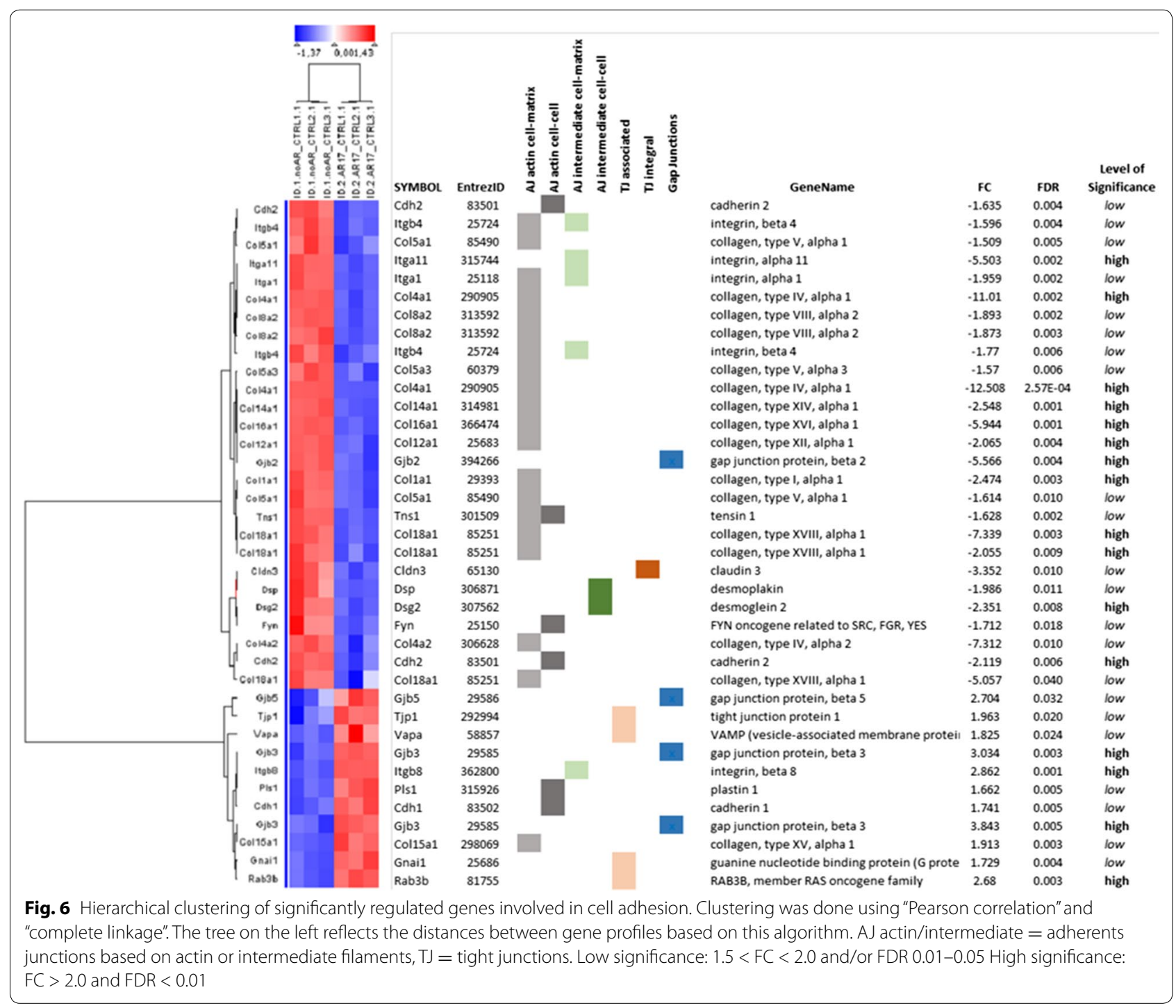

\section{Conclusion}

Our results indicate a severe disturbance of Sertoli cell metabolism, function and cell biology concerning immune status and generation of blood-testis barrier, caused by the transfection procedure even without androgen stimulation of cells. The alterations in gene expression levels might either be related to the transfection procedure itself and/or to the insertion of human AR into $A r$-free rat Sertoli cells. A microarray analysis with mock-transfected Sertoli cell line would be needed to distinguish both possibilities. We consider the altered gene expression to be caused by AR insertion, as many of the altered genes were identified as AR and Sertoli cell specific. In either case, incubation of transfected cell lines with testosterone or dihydrotestosterone might lead to false-positive or false-negative results and additionally, also non-genomic pathways including $\mathrm{AR} / A r$ action may be altered by transfection procedures. Therefore, suitable negative controls are needed for stimulation experiments with T or DHT, i.e. non-transfected cells as appropriate negative controls. Gene expression has to be normalized by these non-transfected cells to avoid false-positive or false-negative results regarding gene regulation.

\section{Methods}

\section{Cell lines and culture conditions, human positive control tissue}

We determined the expression of $A r$ in different Sertoli cell lines by RT-PCR. For this study, we used four existing immortalized Sertoli cell lines from either mouse (WL3, SK-11) [40, 41] or rat testis (93RS2) [18] kindly provided by our collaborators. Additionally, SCIT-C 8 cells were generated from immortalized Sertoli cells from rat testis as described by Konrad et al. [42]. We did not conduct 
any animal research in our study and therefore ethics approval was not required. Total RNA of these cells was isolated by peqGold Total RNA Kit (Peqlab, Erlangen, Germany), set to a concentration of $200 \mathrm{ng} / \mu \mathrm{l}$ and genomic DNA was digested by RNase-Free DNase Set (Qiagen, Hilden, Germany). Reverse transcription was performed with Omniscript RT Kit (Qiagen). The mastermix was prepared as follows: $2 \mu$ Buffer RT $(10 \times)$, $2 \mu \mathrm{l}$ dNTP mix (5 mM each), 0,7 $\mu \mathrm{l}$ RNAse inhibitor (20 units/ $\mu$ l, Invitrogen via LifeTechnologies, Carlsbad, CA, USA), 0,2 $\mu$ l Oligo-dT primer $(10 \mu \mathrm{M}$, Qiagen $)$ and $1 \mu \mathrm{l}$ Omniscript Reverse Transcriptase were mixed and RNase free water was added to a final volume of $10 \mu \mathrm{l}$. To test genomic DNA digestion success, we omitted reverse transcriptase and replaced it by RNase free water for one reaction. After addition of $1 \mu \mathrm{l} \mathrm{RNA}(200 \mu \mathrm{g} / \mu \mathrm{l})$, we incubated the reaction mix for $1 \mathrm{~h}$ at $37^{\circ} \mathrm{C}$. cDNA not directly used for further experiments was stored at $-20{ }^{\circ} \mathrm{C}$. Amplification of $A r$ was achieved with a matching primer pair for murine and rat $A r$ obtained from Eurofins MWG Operon (Huntsville, AL, USA) as can be seen in Table 7 and Taq PCR Master Mix Kit (Qiagen). Mastermix was prepared as follows: $34 \mu \mathrm{laq}$ PCR Master Mix, forward and reverse primer $(2,5 \mu \mathrm{l}$ each) and RNase free water as well as $1 \mu \mathrm{l}$ cDNA were mixed to a final volume of $50 \mu \mathrm{l}$. Amplification was performed with $1 \times 94{ }^{\circ} \mathrm{C}$ for $4 \mathrm{~min}$, $35 \times\left(94{ }^{\circ} \mathrm{C}\right.$ for $40 \mathrm{~s}, 60^{\circ} \mathrm{C}$ for $45 \mathrm{~s}, 72{ }^{\circ} \mathrm{C}$ for $\left.90 \mathrm{~s}\right)$ and $1 \times$ $72{ }^{\circ} \mathrm{C}$ for $5 \mathrm{~min}$.

As the prepubertal rat Sertoli cell line 93RS2 proved to be devoid of $A r$, we chose this cell line for further experiments. The cells were maintained in a $5 \% \mathrm{CO}_{2}$ atmosphere at $34{ }^{\circ} \mathrm{C}$. The standard culture media consists of DMEM high glucose mixed 1:1 with Ham's F-12 media plus 100 units $/ \mathrm{ml}$ penicillin, $0,1 \mathrm{mg} / \mathrm{ml}$ streptomycin, $10 \%$ FBS-Gold (total protein 3.0-4.5 g/dl), and $1 \%$ ITS (1000 mg/l Insulin, 550 mg/l Transferrin, 0.68 mg/l Selenin). Unless otherwise stated, cell culture media were purchased from Invitrogen (via Life Technologies, Carlsbad, CA, USA).

\section{Ethics, consent and permissions}

For positive control used in RT-PCR and Western Blotting, we used testis homogenate from a patient showing normal spermatogenesis attending the andological clinic in Münster for re-fertilization surgery. After written informed consent, biopsies were taken under general anesthesia. The reported study has been approved by the Ethics committee of the Medical Faculty of the Justus Liebig University Giessen (decision 75/00 and 56/05).

\section{AR transfection in 93RS2 Sertoli cells}

We introduced a commercial available full length human AR (OriGene, Rockville, MD, USA), containing 17 CAG triplets, into the expression vector pcDNA 6.2 C-EmGFP (Invitrogen) after amplification of AR using GC-Rich PCR System (Roche, Basel, Switzerland), according to manufacturer's instructions. Transfection of 93RS2 cells was performed using the microporation system MP-100 (Peqlab). Cells were detached by Trypsin (PAA, Piscataway, NY, USA) and subsequently adjusted to 200,000 cells per well in a 6-well-plate. After re-suspending the cells in the provided buffer, plasmid DNA was added. We used a current strength of $1150 \mathrm{~V}$ for $20 \mathrm{~ms}$ with two pulses.

\section{Validation of transfection success in 93RS2 by immunofluorescence, RT-PCR and Western Blotting}

$24 \mathrm{~h}$ after transfection, transfected cells (93RShAR17) were fixed in 6-well-plates with $4 \%$ paraformaldehyde for $20 \mathrm{~min}$ at room temperature, washed three times with PBS and permeabilized with $0.1 \%$ Triton $\mathrm{x}-100$. After transferring the cells to a 12-well-plate and washing with PBS, unspecific binding sites were blocked with $3 \%$ BSA (bovine serum albumin, Carl Roth $\mathrm{GmbH}+\mathrm{Co}$. KG, Karlsruhe, Germany) in TBST (Tris-Buffered Saline and Tween 20, Carl Roth) and washed again with PBS. The rabbit anti-GFP antibody (ab290, Abcam, Cambrigde, UK) was added in a dilution of 1:200. After incubation for $3 \mathrm{~h}$ and washing with PBS, goat anti-rabbit Alexa 488 antibody (Invitrogen) was added in a dilution of 1:200. After a final incubation for $1 \mathrm{~h}$ in the dark, cells were washed and embedded with Vectashield mounting medium with DAPI (H-1200, Vector Laboratories, Dossenheim, Germany). Transfection efficiency was evaluated using a fluorescence microscope (AxioPhot, Zeiss, Oberkochen, Germany). Western Blot analysis to prove antibody specificity and AR protein expression in transfected Sertoli cells was performed as described elsewhere [43]. Shortly, proteins extracted from cell lysates of transfected 93RS2 cells and human testis tissue were submitted to protein extraction using TRI Reagent ${ }^{\circledR}$ RNA Isolation Reagent (Sigma-Aldrich, St. Louis, MO, USA) according to Chomczynski [44]. Proteins were run on a 3-8 \% Tris-acetate gel (Life Technologies, Carlsbad, CA, USA) for $75 \mathrm{~min}$ at $150 \mathrm{~V}$ and blotted on nitrocellulose membrane for $75 \mathrm{~min}$ at $30 \mathrm{~V}$. A polyclonal rabbit antihuman AR antibody (sc-816, Santa Cruz Biotechnology Inc., Dallas, TX, USA) in a 1:500 dilution and a biotinylated goat anti-rabbit antibody (E0432, Dako, Glostrup, Denmark) in a 1:1000 dilution were used. As weight marker, we used HiMark ${ }^{\mathrm{TM}}$ Pre-Stained Protein Standard (Life Technologies). Signal detection was performed by incubating the membrane with Vectastain Elite ABC Standard Kit (Vector Laboratories, Inc., Burlingame, CA, USA) and TrueBlue ${ }^{\mathrm{TM}}$ Peroxidase Substrate (KPL, Gaithersburg, MD, USA). A negative control was performed by omitting the primary antibody. 
To detect AR mRNA in transfected cells, we performed RT-PCR (primers may be seen in Table 7) as described earlier with minor changes concerning the cycling conditions: $1 \times 94{ }^{\circ} \mathrm{C}$ for $4 \mathrm{~min}, 35 \times\left(94{ }^{\circ} \mathrm{C}\right.$ for $45 \mathrm{~s}, 55{ }^{\circ} \mathrm{C}$ for $45 \mathrm{~s}, 72{ }^{\circ} \mathrm{C}$ for $90 \mathrm{~s}$ ) and $72{ }^{\circ} \mathrm{C}$ for 5 min resulting in a 591 bp amplicon. The CAG repeat length was confirmed using RT-PCR with subsequent high resolution polyacrylamide gel electrophoresis (PAGE) as described recently [45].

\section{RNA isolation for microarray analysis}

Total RNA of transfected 93RShAR17 cells as well as of non-transfected 93RS2 cells (using three technical replicates (N1-N3) each) was extracted using the peqGold total RNA kit (Peqlab) following manufacturer's instructions. The amount of RNA was measured on a BioPhotometer (Eppendorf, Hamburg, Germany) as follows: 93RS2 N1 $2200 \mathrm{ng} / \mu \mathrm{l}, \mathrm{N} 22130 \mathrm{ng} / \mu \mathrm{l}$ and N3 $1920 \mathrm{ng} / \mu \mathrm{l}$ and 93RS2hAR17 N1 $990 \mathrm{ng} / \mu \mathrm{l}, \mathrm{N} 21150 \mathrm{ng} / \mu \mathrm{l}$ and N3 $1065 \mathrm{ng} / \mu \mathrm{l}$ (each replicate with a total volume of $15 \mu \mathrm{l}$ ). RNA was stored after extraction until use at $-80{ }^{\circ} \mathrm{C}$ and transported in liquid nitrogen. The quality of total RNA was checked on a $1 \%$ agarose gel stained with ethidium bromide (Sigma-Aldrich) as well as on Agilent 2100 Bioanalyzer using Eukaryote Total RNA Nano Assay (Agilent Technologies, Santa Clara, CA, USA). For this purpose, RNA was diluted to a concentration of $300 \mathrm{ng} / \mu \mathrm{l}$. Only high quality RNA samples were used for microarray analysis.

\section{Microarray analysis CRNA synthesis and hybridization}

Extracted RNA was transcribed into biotinylated cRNA using MessageAmp ${ }^{\mathrm{TM}}$ II-Biotin Enhanced Kit (LifeTechnologies). Biotinylated cRNA again was quality checked on Agilent 2100 Bioanalyzer as stated above followed by cRNA fragmentation and finally hybridization on CodeLink Rat Whole Genome using the CodeLink Expression Assay Kit (GE Healthcare, Chalfont St. Giles, Buckinghamshire, UK). For this, $10 \mu \mathrm{g}$ cRNA was diluted with nuclease-free water to final volume of $20 \mu \mathrm{l}$ and mixed with $5 \mu$ fragmentation buffer (taken from CodeLink iExpress iAmplify cRNA Prep \& Hyb Kit, GE Healthcare) and fragmented at $94{ }^{\circ} \mathrm{C}$ for $20 \mathrm{~min}$ and subsequent cooling to $0{ }^{\circ} \mathrm{C}$ on ice. Hybridization solution was prepared by mixing hybridization buffer component $\mathrm{A}$ and $\mathrm{B}$ (taken from CodeLink iExpress iAmplify cRNA Prep \& Hyb Kit), nuclease-free water and $25 \mu \mathrm{l}$ fragmented cRNA. Denaturation of cRNA was performed at $90{ }^{\circ} \mathrm{C}$ for $5 \mathrm{~min}$ with subsequent cooling on ice. Hybridization reaction was carried out at $37{ }^{\circ} \mathrm{C}$ for $18 \mathrm{~h}$. Subsequent washing was performed with $0.75 \times$ TNT $(1 \mathrm{M}$ Tris- $\mathrm{HCl}, 5 \mathrm{M}$ $\mathrm{NaCl}$ and $20 \%$ Tween 20) buffer. Bioarrays were stained with $\mathrm{Cy} 5^{\mathrm{TM}}$-streptavadin (GE Healthcare) and scanned using the GenePix ${ }^{\circledR} 4000$ B scanner and the GenePix Pro 4.0 Software (Axon Instruments, Arlington, USA). Scan resolution was set to 5 microns. A total of $2 \times 3=6$ array images were subjected to data analysis. Spot signals of CodeLink bioarrays were quantified using the CodeLink System Software 5.0.0.31312 which generated local background corrected raw as well as median centred intraslide normalized data.

\section{Quality control of microarray data}

The genes represented by probe sets were annotated using the biocLite package (BioConductor) with the library "rwgcod.db" for CodeLink Rat Whole Genome arrays. The intra-slide normalized data containing 35129 rows and 6 columns (200 k values) were processed by an automated workflow that includes omission of control genes $(n=1280)$, removal of genes with poor QC $(\mathrm{n}=1300$ values, $0.6 \%)$ or negative sign $(\mathrm{n}=1603$ values, $0.8 \%$ ), removal of probe sets with too high proportion ( $\geq 50 \%)$ of missing values per group $(\mathrm{n}=203$ probe sets, $0.5 \%$ ) or with not any group having at least $50 \%$ of values flagged as " $\mathrm{G}=$ good" and $50 \%$ values above threshold ( $\mathrm{n}=7177$ probe sets, $21.2 \%$ ), removal of outliers (expression values deviating more than fourfold from the group median, $n=427$ values, $0.3 \%$ ). A total of 26452 probe sets remained after quality control with 1257 probe sets $(=4.7 \%)$ containing 1235 missing values (=0.8\%).

Remaining missing values were imputed by probabilistic principal component analysis (PPCA) using the R-package pca Methods. Imputed dataset was quantile normalized using the R-package limma [46], and logarithm for the base 2 was calculated.

\section{Differential gene expression}

Students $t$ test was applied and a false discovery rate (FDR) $\leq 0.01$ was set for the significance level with an absolute fold change (FC) $\geq 2$ between transfected and non-transfected cells.

\section{Functional gene analysis: overrepresentation analysis}

Enriched functional gene ontology (GO) categories within the differentially regulated genes were determined using DAVID version 6.7 [47, 48]. Functional annotation clustering as well as an enrichment score was calculated for each cluster.

\section{Upstream regulation analysis}

To identify the regulators responsible for the observed gene expression profiles, we performed prediction analysis for activation or inhibition of upstream regulators using the Ingenuity ${ }^{\circledR}$ Pathway Analyzer and the 
Table 7 Primer sequences

\begin{tabular}{|c|c|c|c|c|c|}
\hline \multirow{2}{*}{$\begin{array}{l}\text { Primer name } \\
\text { Ar }\end{array}$} & \multirow{2}{*}{$\begin{array}{l}\text { GenBank accession no. } \\
\text { NM_013476 }\end{array}$} & \multicolumn{2}{|c|}{ Sequence $\left(5^{\prime} \geq 3^{\prime}\right)$} & \multirow{2}{*}{$\begin{array}{l}\begin{array}{l}\text { Amplicon } \\
\text { length (bp) }\end{array} \\
181\end{array}$} & \multirow{2}{*}{$\begin{array}{l}\begin{array}{l}\text { RT-qPCR } \\
\text { efficiency (\%) }\end{array} \\
\text { n.a. }\end{array}$} \\
\hline & & For & CACATCCTGCTCAAGGCGCTT & & \\
\hline & (mouse) & Rev & CCCAGAAAGGATCTTGGGCAC & & \\
\hline & NM_012502 & & & 181 & n.a. \\
\hline & (rat) & & & & \\
\hline \multirow[t]{2}{*}{$A R$} & NM_000044 & For & TATCCCAGTCCCACTTGTG & 592 & n.a. \\
\hline & & Rev & TCTCTCCCAGTTCATTGAGG & & \\
\hline \multirow[t]{2}{*}{ Aldhia2 } & NM_053896 & For & TCAGACTTCGGGCTTGTAGC & 125 & 94.3 \\
\hline & & Rev & GGGCTCTGAGCATTTAAGGC & & \\
\hline \multirow[t]{2}{*}{ Apoe } & NM_001270681 & For & TGATGGAGGACACTATGACG & 188 & 105.8 \\
\hline & & Rev & CATGGTGTTTACCTCGTTGC & & \\
\hline \multirow[t]{2}{*}{ Bambi } & NM_139082 & For & CCATGCCCACTTTGGAATGC & 126 & 128.0 \\
\hline & & Rev & TTCTGCTGCTGTCATGCTGG & & \\
\hline \multirow[t]{2}{*}{ Cdknia } & NM_080782 & For & CACAGGAGCAAAGTATGCCG & 125 & 135.1 \\
\hline & & Rev & GCGAAGTCAAAGTTCCACCG & & \\
\hline \multirow[t]{2}{*}{ Col4al } & NM_0011350009 & For & GGAGAACCTGGCAGTGATG & 118 & 99.9 \\
\hline & & Rev & CACCCTTGGAACCTTTGTC & & \\
\hline \multirow[t]{2}{*}{ Dhh } & NM_053367 & For & TTGGCACTCCTGGCACTATC & 124 & 102.2 \\
\hline & & Rev & CGGGCATACTAGGCACAAAC & & \\
\hline \multirow[t]{2}{*}{ Egr1 } & NM_012551 & For & GTGGGAGAAAGTTTGCCAGG & 125 & 111.3 \\
\hline & & Rev & GTAGGAAGAGAGGGAAGAGG & & \\
\hline \multirow[t]{2}{*}{ Fgfr2 } & NM_012712 & For & CAGCTTCCCCAGATTACCTG & 92 & 94.4 \\
\hline & & Rev & CATTCGGCAAAAGATGACTG & & \\
\hline \multirow[t]{2}{*}{ Fst } & NM_012561 & For & TCCAGTACCAGGGCAAATG & 78 & 96.2 \\
\hline & & Rev & TCTGATCCACCACACAAGTG & & \\
\hline \multirow[t]{2}{*}{ Gjal } & NM_012567 & For & GTACGGGATTGAAGAGCACG & 119 & 105.5 \\
\hline & & Rev & TGTACCACTGGATGAGCAGG & & \\
\hline \multirow[t]{2}{*}{ Hsd17b10 } & NM_031682 & For & GAGGAAACTGCATATTTGCC & 106 & 110.5 \\
\hline & & Rev & TTGACAGCCACATCTATACG & & \\
\hline \multirow[t]{2}{*}{ Inhbb } & NM_080771 & Rev & ACGGGTCAAGGTGTACTTCC & 96 & 100.3 \\
\hline & & For & AAGGTATGCCAGCCACTACG & & \\
\hline \multirow[t]{2}{*}{ Myc } & NM_0123603 & Rev & TACATCCTGTCCGTTCAAGC & 67 & 108.0 \\
\hline & & For & GCCGTTTCCTCAGTAAGTCC & & \\
\hline \multirow[t]{2}{*}{ Ncam1 } & NM_031521 & Rev & ACGATGATGACTCCTCTACC & 150 & 94.1 \\
\hline & & For & GCGCATTCTTGAACATGAGC & & \\
\hline \multirow[t]{2}{*}{ Pmepal } & NM_001107807 & Rev & TGGTGATGGTGGTGATGATC & 76 & 134.2 \\
\hline & & For & CTGTGTCGGCTGATGAAGG & & \\
\hline \multirow[t]{2}{*}{ Ptsg2 } & NM_017232 & Rev & ACCGTGGTGAATGTATGAGC & 104 & 98.4 \\
\hline & & For & TCTTGTCAGAAACTCAGGCG & & \\
\hline Rarg & NM_001135249 & Rev & TCACCAAGGTCAGCAAAGCC & 125 & 141.9 \\
\hline & & For & ACTGAACTTGTCCCACAGCC & & \\
\hline Rbpl & NM_012733 & Rev & CTTCAGTGTGTTCAGAAGGG & 117 & 87.9 \\
\hline & & For & CTTGAACACTTGCTTGCAGG & & \\
\hline Rplp2 & NM_001030021 & Rev & TTGCCTCTTATCTGCTGGCC & 110 & 103.4 \\
\hline & & For & GTTGAGTCGTTCATCGTCCG & & \\
\hline Sulf2 & NM_001034927 & Rev & TTCCTGCCCAAGTATCAGC & 108 & 111.5 \\
\hline & & For & CCCAGAAGCGTCCTCTACAC & & \\
\hline Tf & NM_001013110 & Rev & TGAGGTCTTGCCACAGAAGG & 125 & 102.4 \\
\hline & & For & CCACAACAGCATGAGAAGGG & & \\
\hline
\end{tabular}


Table 7 continued

\begin{tabular}{|c|c|c|c|c|c|}
\hline \multirow{2}{*}{$\begin{array}{l}\text { Primer name } \\
\text { Tgfb1i1 }\end{array}$} & \multirow{2}{*}{$\begin{array}{l}\text { GenBank accession no. } \\
\text { NM_001191840 }\end{array}$} & \multicolumn{2}{|c|}{ Sequence $\left(5^{\prime} \geq 3^{\prime}\right)$} & \multirow{2}{*}{$\begin{array}{l}\begin{array}{l}\text { Amplicon } \\
\text { length (bp) }\end{array} \\
101\end{array}$} & \multirow{2}{*}{\begin{tabular}{|l}
$\begin{array}{l}\text { RT-qPCR } \\
\text { efficiency (\%) }\end{array}$ \\
106.5
\end{tabular}} \\
\hline & & Rev & ACTACATCTCGGCACTCAGC & & \\
\hline & & For & ACCCTCGTGCTCAAAGAAGC & & \\
\hline \multirow[t]{2}{*}{ Tnfrsfia } & NM_013091 & $\operatorname{Rev}$ & AAAGAGGTGGAGGGTGAAGG & 128 & 101.7 \\
\hline & & For & ACAGGATGACTGAAGCGTGG & & \\
\hline \multirow[t]{2}{*}{$U b c$} & NM_017314 & Rev & GGCAAAGATCCAGGACAAGG & 100 & 99.4 \\
\hline & & For & TTGTAGTCTGACAGGGTGCG & & \\
\hline
\end{tabular}

Sequence and RT-qPCR efficiency of primers used for the study

n.a. not applied

Ingenuity ${ }^{\circledR}$ Knowledge Base (IPA, Qiagen). Prediction is given as a z-score with $>2$ for activated and $<2$ for inactivated upstream regulators.

\section{Validation of microarray results by quantitative $R T-P C R$ (RT-qPCR)}

For validation of microarray data, we performed RTqPCR with 93RShAR17 and non-transfected 93RS2 cells for 22 genes (Table 7) that have been shown to be significantly altered in microarray analysis. All primer pairs obtained from MWG Operon have been validated in standard RT-PCR using rat testis as positive control. For this pupose, total RNA from rat testis was extracted using TRI Reagent ${ }^{\circledR}$ RNA Isolation Reagent (SigmaAldrich) according to Chomczynski [44]. Genomic DNA was digested by using DNase I (Roche). For this, $6,65 \mu \mathrm{l} \mathrm{RNA}(200 \mathrm{ng} / \mu \mathrm{l})$ were incubated with $1 \mu \mathrm{l} \mathrm{MgCl}_{2}$ (25 mM, Thermo Fisher Scientific), $1 \mu$ l DNase Buffer (Roche), 0,25 $\mu$ l RNase inhibitor (40 units/ $\mu l$, Thermo Fisher Scientific) and $1 \mu \mathrm{l}$ DNase I for $25 \mathrm{~min}$ at $37^{\circ} \mathrm{C}$ in a thermocycler. After a enzyme heat inactivation for $5 \mathrm{~min}$ at $75^{\circ} \mathrm{C}$, RNA was immediately reversely transcribed into cDNA. For this, 1,5 $\mu$ l DNase-treated RNA was mixed with $1 \mu \mathrm{l} 10 \mathrm{x}$ PCR Gold Buffer, $2 \mu \mathrm{lgCl}_{2}(25 \mathrm{mM}), 1 \mu \mathrm{l}$ dNTP mix (each 2,5 mM), 0,5 $\mu$ l random hexamer primer (50 mM), 0,5 $\mu \mathrm{l}$ RNase inhibitor (20 units/ $\mu \mathrm{l}), 0,5 \mu \mathrm{l} \mathrm{Mul-}$ tiScribe ${ }^{\circledR}$ Reverse Transcriptase (50 units/ $\mu \mathrm{l}$ ) and RNase free water to a final volume of $9 \mu \mathrm{l}$. All reagents were obtained from Thermo Fisher Scientific. For -RT control, reverse transcriptase was replaced by the same amount of RNase free water. Incubation was performed as follows: $8 \mathrm{~min}$ at $21^{\circ} \mathrm{C}, 15 \mathrm{~min}$ at $42{ }^{\circ} \mathrm{C}$ and $5 \mathrm{~min}$ at $99^{\circ} \mathrm{C}$. cDNA was stored at $-20{ }^{\circ} \mathrm{C}$ until use. For primer validation in standard RT-PCR, $1 \mu \mathrm{l} \mathrm{cDNA}$ was mixed with 2,5 $\mu \mathrm{l} 10 \times$ PCR Gold Buffer, $2 \mu \mathrm{MgCl}_{2}(25 \mathrm{mM}$ ), dNTP mix (each $2.5 \mathrm{mM}), 1 \mu \mathrm{l}$ forward and reverse primer, respectively (each $10 \mathrm{pM}), 0.125 \mu$ l AmpliTaq Gold ${ }^{\circledR}$ DNA Polymerase ( 5 units $/ \mu \mathrm{l}$ ) and RNase free water to a final volume of $25 \mu \mathrm{l}$. Cycling conditions were: $1 \times 94{ }^{\circ} \mathrm{C}$ for $9 \mathrm{~min}, 35 \times$ $\left(94{ }^{\circ} \mathrm{C}\right.$ for $45 \mathrm{~s}, 60{ }^{\circ} \mathrm{C}$ for $45 \mathrm{~s}, 72{ }^{\circ} \mathrm{C}$ for $45 \mathrm{~s}$ ) and $72{ }^{\circ} \mathrm{C}$ for $5 \mathrm{~min}$. Length of the resulting amplicons was checked in an agarose gel electrophoresis as described earlier. For RT-qPCR dilution series we used rat $R p l p$ and $U b c$ as internal reference genes and performed triple determination in a decreasing 10- fold dilution series (undil., 1:10, 1:100). RT-qPCR efficiency (E) has been calculated using Bio-Rad CFX Manager version 3.1 (Bio-Rad) from the standard curve's slope and may be seen in Table 7. Reference genes have been determined by using a TaqMan ${ }^{\circledR}$ Array Rat Endogenous Control Plate (96-well, 32 reference genes pre-plated, Applied Biosystems via Thermo Fisher Scientific, Waltham, MA, USA).

For RT-qPCR, total RNA from transfected and nontransfected cells was extracted using peqGold Total RNA Kit (PEQlab) and reversely transcribed into cDNA as described above. As technical replicates we used cell pellets from three independent passages and for each specimen, double determination was performed using $1 \mu \mathrm{l}$ of cDNA, $4 \mu$ l EvaGreen mastermix (no Rox) (Bio\&Sell, Feucht, Germany), $0.6 \mu \mathrm{l}$ forward and reverse primer each and $12.8 \mu \mathrm{l}$ sterile aqua bidest to a final volume of $20 \mu \mathrm{l}$. RT-qPCR conditions were $1 \times 95^{\circ} \mathrm{C}$ for $15 \mathrm{~min}$, $40 \times\left(95^{\circ} \mathrm{C}\right.$ for $15 \mathrm{~s}, 60{ }^{\circ} \mathrm{C}$ for $30 \mathrm{~s}, 72^{\circ} \mathrm{C}$ for $\left.20 \mathrm{~s}\right)$ followed by melt curve analysis $\left(1 \times 95^{\circ} \mathrm{C}\right.$ for $10 \mathrm{~s}, 65^{\circ} \mathrm{C}$ to $95^{\circ} \mathrm{C}$, increment $0.5{ }^{\circ} \mathrm{C}$ for $5 \mathrm{~s}$ ) on a CFX96 RealTime cycler (Bio-Rad Laboratories, Hercules, CA, USA). Relative gene expression was calculated by the $2^{-\Delta \Delta \mathrm{Cq}}$ method, using Rplp and $U b c$ as internal reference genes. Expression levels represent $x$ fold higher expression in the transfected than in the non-transfected cells (set as "1"). For statistical analysis, differences of the mean were assessed by ANOVA analysis. P-values of $\mathrm{p} \leq 0.05$ are set as statistically significant. The $\mathrm{C}_{\mathrm{q}}$ values for all transcripts may be seen in Additional file 1: Table S1.

\section{Availability of supporting data}

Complete microarray data may be found on GEO Accession Viewer database [19] with accession number GSE57653. Single Sertoli cell line data may be found under accession numbers GSM1385418 (Sertoli Cell 
Line noAR_1), GSM1385419 (Sertoli Cell Line noAR_2), GSM1386001 (Sertoli Cell Line noAR_3), GSM1385420 (Sertoli Cell Line AR17_1), GSM1385421 (Sertoli Cell Line AR17_2), GSM1385422 (Sertoli Cell Line AR17_3). Raw data of RT-qPCR experiments can be seen in Additional file 1: Table S1.

\section{Additional file}

Addtional file 1: Table S1. Contains raw data $\left(C_{q}\right.$ values of reference and target genes) of quantitative RT-PCR analysis.

\begin{abstract}
Abbreviations
93RS2, SCIT-C8: rat Sertoli cell lines; 93RShAR17: with human AR transfected 93RS cells; AIS: androgen insensitivity syndrome; Amh: anti-muellerian hormone; AR/Ar: androgen receptor; ARE: androgen responsive element; Bambi: BMP and activin membrane-bound inhibitor; $C \mathrm{Cl}$ : chemokine (C-C motif) ligand 5; Ckdn 1a: cyclin-dependent kinase inhibitor 1a; CDS: coding DNA sequence; Col4a1: collagen type IV alpha 1; Cox2: cyclooxygenase 2; Cybrd1: cytochrome $b$ reductase 1; DBD: DNA binding domain; Dhh: desert hedgehog; DHT: dihydrotestosterone; Egr1: early growth response 1; FBS: fetal bovine serum; FC: fold change; FDR: false discovery rate; Fgfr2: fibroblast growth factor receptor 2; Fst: follistatin; Gja1: gap junction protein alpha 1; GO: gene ontology; IF: immunofluorescence; Ifnb1: interferon beta 1, fibroblast; Ifr7: interferon regulatory factor 7 ; II-1 $\beta$ : interleukin $1 \beta$; Inhbb: inhibin beta B; IPA: Ingenuity ${ }^{\circledR}$ Pathway Analyzer; ITS: insulin-transferrin-selenin; TJ: tight junctions; LBD: ligand binding domain; Myc: myelocytomastosis oncogene; NTC: no template control; PAGE: polyacrylamide gel electrophoresis; PBS: phosphate buffered saline; Pmepa 1: prostate transmembrane protein, androgen induced 1; PPCA: probabilistic principal component analysis; Ptsg2: prostaglandin-endoperoxide synthase 2; Rarg: retinoid acid receptor, gamma; Rplp: ribosomal protein I 16; RT-PCR: reverse transcription polymerase chain reaction; RT-qPCR: quantitative RT-PCR; SK-11:WL3 mouse Sertoli cell lines; Smad 1: SMAD familiy member 1; Sox9: Sry-box 9; Sry: sex determining reagion on Y chromosome; Steap2: six-transmembrane epithelial antigen of the prostate $2 ; \mathrm{T}$ : testosterone; TBST: Tris-Buffered Saline and Tween 20; Tf: transferrin; Tgfb 1i1: transforming growth factor beta 1 induced transcript 1; Tnfrsf1a: tumor necrosis factor receptor superfamily, member 1a; Ubc: ubiquitin c.
\end{abstract}

\section{Authors' contributions}

DF and MM drafted the manuscript and performed quantitative RT-PCR, microarray analysis and statistical analysis, respectively. DL performed screening for cell lines, transfection, and immunofluorescence staining. KL was responsible for study design and supervision of the transfection procedure; furthermore he was involved in cell line acquisition and cell culture experiments. GJ supervised transfection procedure as well and generously provided the AR-GFP construct. KS provided human testis material for positive control purposes. Both GJ and KS critically revised the manuscript. CT and $\mathrm{HH}$ participated in the design of microarray experiments and $\mathrm{HH}$ also helped to draft the manuscript. MB was responsible for study design, supervision and critically revised the manuscript. All authors read and approved the final manuscript.

\section{Author details}

${ }^{1}$ Institute of Veterinary Anatomy, Histology and Embryology, Justus Liebig University, Frankfurter Straße 98, 35392 Giessen, Germany. ${ }^{2}$ Institute of Medical Microbiology, Justus Liebig University, Giessen, Germany. ${ }^{3}$ Department of Gynecology and Obstetrics, Justus Liebig University, Giessen, Germany. ${ }^{4}$ Department of Clinical Andrology, Centre for Reproductive Medicine and Andrology, University Clinic Münster, Münster, Germany.

\section{Acknowledgements}

The authors want to thank J. Vogelsberg and D. Zoltan for their skilful technical assistance. Cell lines were generously provided by Profs. Korach, Boekelheide and Gromoll. The presented study was funded by German Research Foundation (DFG KFO181, BE1061/7-1).

\section{Competing interests}

The authors declare that they have no competing interests.

Received: 3 August 2015 Accepted: 9 December 2015 Published online: 29 December 2015

\section{References}

1. Walker WH. Molecular mechanisms of testosterone action in spermatogenesis. Steroids. 2009;74(7):602-7.

2. Gelmann EP. Molecular biology of the androgen receptor. J Clin Oncol. 2002;20(13):3001-15.

3. Yong EL, Loy CJ, Sim KS. Androgen receptor gene and male infertility. Hum Reprod Update. 2003;9(1):1-7.

4. Coffey K, Robson CN. Regulation of the androgen receptor by post-translational modifications. J Endocrinol. 2012;215(2):221-37.

5. Bergh A, Damber JE. Immunohistochemical demonstration of androgen receptors on testicular blood vessels. Int J Androl. 1992;15(5):425-34.

6. Sertoli E. Dell'esistenza di particolari cellule ramificante nei cunalicoli seminiferi del testicoli umano. Morgagni. 1865;7:31-40.

7. Lee $\mathrm{H}$, Chang $\mathrm{C}$. Recent advances in androgen receptor action. Cell Mol Life Sci. 2003;60(8):1613-22.

8. Willems A, Batlouni SR, Esnal A, Swinnen JV, Saunders PTK, Sharpe RM, et al. Selective ablation of the androgen receptor in mouse sertoli cells affects sertoli cell maturation, barrier formation and cytoskeletal development. PLoS One. 2010;5(11):e14168.

9. Ortmann J, Prifti S, Bohlmann MK, Rehberger-Schneider S, Strowitzki T, Rabe T. Testosterone and 5 alpha-dihydrotestosterone inhibit in vitro growth of human breast cancer cell lines. Gynecol Endocrinol. 2002;16(2):113-20.

10. Jaroenporn S, Furuta C, Nagaoka K, Watanabe G, Taya K. Comparative effects of prolactin versus ACTH, estradiol, progesterone, testosterone, and dihydrotestosterone on cortisol release and proliferation of the adrenocortical carcinoma cell line H295R. Endocrinology. 2008;33(2):205-9.

11. Pronsato L, Boland R, Milanesi L. Testosterone exerts antiapoptotic effects against $\mathrm{H}_{2} \mathrm{O} 2$ in C2C12 skeletal muscle cells through the apoptotic intrinsic pathway. J Endocrinol. 2012;212(3):371-81.

12. Chen G, Li S, Dong X, Bai Y, Chen A, Yang S, et al. Investigation of testosterone, androstenone, and estradiol metabolism in HepG2 cells and primary culture pig hepatocytes and their effects on 17ßHSD7 gene expression. PLoS One. 2012;7(12):e52255.

13. Yeh S, Hu Y, Wang P, Xie C, Xu Q, Tsai M, et al. Abnormal mammary gland development and growth retardation in female mice and MCF7 breast cancer cells lacking androgen receptor. J Exp Med. 2003;198(12):1899-908.

14. Szelei J, Jimenez J, Soto AM, Luizzi MF, Sonnenschein C. Androgeninduced inhibition of proliferation in human breast cancer MCF7 cells transfected with androgen receptor. Endocrinology. 1997;138(4):1406-12.

15. Yuan S, Trachtenberg J, Mills GB, Brown TJ, Xu F, Keating A. Androgeninduced inhibition of cell proliferation in an androgen-insensitive prostate cancer cell line (PC-3) transfected with a human androgen receptor complementary DNA. Cancer Res. 1993;53(6):1304-11.

16. Xiao Y, Karnati S, Qian G, Nenicu A, Fan W, Tchatalbachev S, et al. Cremediated stress affects sirtuin expression levels, peroxisome biogenesis and metabolism, antioxidant and proinflammatory signaling pathways. PLoS One. 2012;7(7):e41097.

17. Li Y, Chan SC, Brand LJ, Hwang TH, Silverstein KAT, Dehm SM. Androgen receptor splice variants mediate enzalutamide resistance in castrationresistant prostate cancer cell lines. Cancer Res. 2013;73(2):483-9.

18. Jiang C, Hall SJ, Boekelheide K. Development and characterization of a prepubertal rat Sertoli cell line, 93RS2. J Androl. 1997;18(4):393-9.

19. GEO Accession viewer. http://www.ncbi.nlm.nih.gov/ gds/?term=GSE57653 Accession 15 May 2014.

20. Bitgood MJ, Shen L, McMahon AP. Sertoli cell signaling by Desert hedgehog regulates the male germline. Curr Biol. 1996;6(3):298-304.

21. Weider K, Bergmann M, Brehm R. Connexin 43: its regulatory role in testicular junction dynamics and spermatogenesis. Histol Histopathol. 2011;26(10):1343-52. 
22. Sharpe RM, McKinnell C, Kivlin C, Fisher JS. Proliferation and functional maturation of Sertoli cells, and their relevance to disorders of testis function in adulthood. Reproduction. 2003;125(6):769-84.

23. Skinner MK, Schlitz SM, Anthony CT. Regulation of Sertoli cell differentiated function: testicular transferrin and androgen-binding protein expression. Endocrinology. 1989;124(6):3015-24.

24. Barakat B, Itman C, Mendis SH, Loveland KL. Activins and inhibins in mammalian testis development: new models, new insights. Mol Cell Endocrinol. 2012;359(1-2):66-77.

25. Ashe PC, Berry MD. Apoptotic signaling cascades. Prog Neuropsychopharmacol Biol Psychiatry. 2003;27(2):199-214

26. Jacobsen L, Calvin S, Lobenhofer E. Transcriptional effects of transfection: the potential for misinterpretation of gene expression data generated from transiently transfected cells. Biotechniques. 2009;47(1):617-24.

27. Li F, Yamaguchi K, Okada K, Matsushita K, Enatsu N, Chiba K, et al. Efficient transfection of DNA into primarily cultured rat sertoli cells by electroporation. Biol Reprod. 2013;88(3):61.

28. Leichtmann-Bardoogo Y, Cohen LA, Weiss A, Marohn B, Schubert S, Meinhardt $A$, et al. Compartmentalization and regulation of iron metabolism proteins protect male germ cells from iron overload. Am J Physiol Endocrinol Metab. 2012;302(12):E1519-30.

29. Skinner MK, Griswold MD. Sertoli cells synthesize and secrete transferrinlike protein. J Biol Chem. 1980;255(20):9523-5.

30. Matzkin ME, Mayerhofer A, Rossi SP, Gonzalez B, Gonzalez CR, GonzalezCalvar SI, et al. Cyclooxygenase-2 in testes of infertile men: evidence for the induction of prostaglandin synthesis by interleukin-1 $\beta$. Fertil Steril. 2010;94(5):1933-6.

31. Yamaguchi K, Ishikawa T, Kondo Y, Fujisawa M. Cisplatin regulates Sertoli cell expression of transferrin and interleukins. Mol Cell Endocrinol. 2008;283(1-2):68-75.

32. Sledz CA, Holko M, de Veer MJ, Silverman RH, Williams BR. Activation of the interferon system by short-interfering RNAs. Nat Cell Biol. 2003;5(9):834-9.

33. Bitgood MJ, McMahon AP. Hedgehog and Bmp genes are coexpressed at many diverse sites of cell-cell interaction in the mouse embryo. Dev Biol. 1995; 172(1):126-38

34. Clark AM, Garland KK, Russell LD. Desert hedgehog (Dhh) gene is required in the mouse testis for formation of adult-type Leydig cells and normal development of peritubular cells and seminiferous tubules. Biol Reprod. 2000;63(6):1825-38

35. Mäkelä J, Saario V, Bourguiba-Hachemi S, Nurmio M, Jahnukainen K, Parvinen $\mathrm{M}$, et al. Hedgehog signalling promotes germ cell survival in the rat testis. Reproduction. 2011;142(5):711-21.
36. Schmahl J, Kim Y, Colvin JS, Ornitz DM, Capel B. Fgf9 induces proliferation and nuclear localization of FGFR2 in Sertoli precursors during male sex determination. Development. 2004;131(15):3627-36.

37. Bagheri-Fam S, Sim H, Bernard P, Jayakody I, Taketo MM, Scherer G, et al. Loss of Fgfr2 leads to partial XY sex reversal. Dev Biol. 2008;314(1):71-83.

38. Valeri C, Schteingart HF, Rey RA. The prepubertal testis: biomarkers and functions. Curr Opin Endocrinol Diabetes Obes. 2013;20(3):224-33.

39. Pfaff T, Rhodes J, Bergmann M, Weinbauer GF. Inhibin B as a marker of sertoli cell damage and spermatogenic disturbance in the rat. Birth Defects Res B Dev Reprod Toxicol. 2013;98(1):91-103.

40. Mueller SO, Korach KS. Immortalized testis cell lines from estrogen receptor (ER) alpha knock-out and wild-type mice expressing functional ERalpha or ERbeta. J Androl. 2001:22(4):652-64.

41. Sneddon SF, Walther N, Saunders PTK. Expression of androgen and estrogen receptors in sertoli cells: studies using the mouse SK11 cell line. Endocrinology. 2005; 146(12):5304-12.

42. Konrad L, Munir Keilani M, Cordes A, Völck-Badouin E, Laible L, Albrecht M et al. Rat Sertoli cells express epithelial but also mesenchymal genes after immortalization with SV40. Biochim Biophys Acta. 2005;1722(1):6-14.

43. Weider K, Bergmann M, Giese S, Guillou F, Failing K, Brehm R. Altered differentiation and clustering of Sertoli cells in transgenic mice showing a Sertoli cell specific knockout of the connexin 43 gene. Differentiation. 2011;82(1):38-49.

44. Chomczynski P. A reagent for the single-step simultaneous isolation of RNA, DNA and proteins from cell and tissue samples. BioTechniques. 1993;15(3):532-4

45. Fietz D, Geyer J, Kliesch S, Gromoll J, Bergmann M. Evaluation of CAG repeat length of androgen receptor expressing cells in human testes showing different pictures of spermatogenic impairment. Histochem Cell Biol. 2011;136(6):689-97

46. Bolstad BM, Irizarry RA, Astrand M, Speed TP. A comparison of normalization methods for high density oligonucleotide array data based on variance and bias. Bioinformatics. 2003;19(2):185-93.

47. Dennis G, Sherman BT, Hosack DA, Yang J, Gao W, Lane HC, et al. DAVID: database for annotation, visualization, and integrated discovery. Genome Biol. 2003;4(5):P3

48. Huang DW, Sherman BT, Lempicki RA. Systematic and integrative analysis of large gene lists using DAVID bioinformatics resources. Nat Protoc. 2009:4(1):44-57

\section{Submit your next manuscript to BioMed Central and we will help you at every step:}

- We accept pre-submission inquiries

- Our selector tool helps you to find the most relevant journal

- We provide round the clock customer support

- Convenient online submission

- Thorough peer review

- Inclusion in PubMed and all major indexing services

- Maximum visibility for your research

Submit your manuscript at www.biomedcentral.com/submit 